\title{
Perfil dos métodos de análise mais usados na avaliação da influência da vegetação na temperatura do ar em ambientes externos no Brasil
}

\author{
ALMEIDA, Marco Antonio Milazzo de ${ }^{1}$ \\ VASCONCELLOS, Virgínia Maria Nogueira de ${ }^{2}$ \\ 1ProArq, UFRJ, Rio de Janeiro, Brasil, milazzo@ufrj.br \\ 2 ProArq, UFRJ, Rio de Janeiro, Brasil, virginia.vasconcellos@gmail.com
}

\begin{abstract}
Resumo
Este artigo tem o objetivo de apresentar um perfil de trabalhos que abordam a influência da vegetação na temperatura do ar em ambientes externos, destacando a situação do suporte físico, o clima analisado e o respectivo método de análise, no Brasil, nas últimas décadas, visando a identificar as características mais recorrentes. Como metodologia, o trabalho compilou e analisou documentos referentes a dissertações, teses e artigos científicos, sobre o tema. Verifica-se que: [1] todos os documentos analisados comprovaram que a temperatura do ar em locais onde há a presença de vegetação é menor que em ambientes onde não há vegetação; [2] a maioria dos estudos adota as medições de campo como principal método de análise; [3] são necessárias mais pesquisas para consolidar a real contribuição da vegetação para o conforto térmico em todos os climas encontrados no Brasil, para diferentes tipos de vegetação, tipos de suporte, quantidade de vegetação e a sua distribuição.
\end{abstract}

Palavras-Chave: vegetação; temperatura do ar; conforto térmico, ilha de calor, clima urbano.

\begin{abstract}
The objective of this paper is to present a profile of works about the influence of vegetation on air temperature mitigation in outdoor environments, highlighting the vegetation physical support, the analyzed climate and the respective method of analysis in Brazil in the last decades, in order to identify the most recurrent characteristics. As a methodology, this research compiled and analyzed dissertations, theses and scientific papers. It is verified that: [1] all the analyzed documents proved that the air temperature in places where the vegetation is present is colder than in environments where there is no vegetation; [2] most studies adopt field measurements as the main method of analysis; [3] further research is needed to consolidate the real contribution of vegetation to thermal comfort in all Brazilian climates, for different types of vegetation, types of support, amount of vegetation and their distribution.
\end{abstract}

Key-Words: vegetation; air temperature; thermal comfort, heat island, urban climate. 


\section{Introdução}

Hoje, no Brasil, já existe um número significativo de trabalhos voltados para o estudo da influência que a vegetação proporciona na temperatura do ar dos ambientes urbanos. Todavia, também é verdadeiro afirmar que, pelas inúmeras espécies vegetais existentes na flora brasileira e suas especificidades, pelas diferenças físico-espaciais de cada espaço observado e pelas distintas situações climáticas encontradas num país de dimensões continentais, ainda falta muito material a ser produzido sobre o papel da vegetação nos ambientes urbanos e sobre seus métodos de análise.

Este artigo tem como objetivo principal, levantar e difundir o perfil da produção acadêmica sobre os diferentes métodos de análise que abordam a questão, como teses, dissertações e artigos produzidos, para verificar sua representatividade no meio acadêmico.

Dentre os fatores que podem influenciar na qualidade dos espaços urbanos, os fatores climáticos são muito importantes, sobretudo quando alinhados à forma urbana. Segundo Lois e Labaki (2001), as atividades dos habitantes urbanos necessitam de ambientes que sejam confortáveis termicamente. Um dos principais motivos para a mudança de temperatura é a substituição das áreas verdes por edificações e pavimentações utilizando materiais construtivos que promovem a impermeabilidade do solo e o acúmulo do calor, que depois é liberado no ambiente (TAHA, 1997). As concentrações de calor, em regiões específicas da cidade, são denominadas ilhas de calor urbano, e colaboram com o desconforto térmico e com o aumento do consumo de energia nas cidades (SANTAMOURIS, 2001).

Com o aumento da temperatura do ar dos ambientes externos, a demanda por eletricidade necessária para alimentar os sistemas de condicionamento de ar tende a aumentar de $2 \%$ a $4 \%$ para cada acréscimo de 1ํ C (AKBARI, 2001). A inserção de árvores nos espaços livres de edificação na cidade (calçadas, praças e outros), bem como a utilização de vegetação nas superfícies de fachadas, pisos e coberturas, ajuda muito a redução destas ilhas de calor (GIVONI, 1991). A evapotranspiração das plantas consome energia solar, aumentando o calor latente, e diminuindo o calor sensível, resfriando as suas folhas e consequentemente $o$ ar ao seu redor (GRIMMOND e OKE, 1991). As plantas também geram sombras, que promovem a proteção das pessoas e das superfícies da radiação solar direta (OKE, 1989). Além disso, a vegetação pode afetar o movimento do ar e as trocas de calor (BONAN, 1997).

Apesar do fenômeno das ilhas de calor ser estudo há muito tempo, recentemente houve um grande aumento das pesquisas e publicações sobre o assunto no Brasil. Os estudos utilizando a tecnologia de geoprocessamento para estimar a temperatura da superfície terrestre e a cobertura da vegetação, em várias localidades urbanas confirmaram a hipótese de que a cobertura verde pode ser efetiva na redução da temperatura (HUNG et al., 2006; TIANGCO et al., 2008). Modelos matemáticos e simulações computacionais também podem ser utilizados para investigar e prever os efeitos potenciais do uso da vegetação nos climas urbanos (AVISSAR, 1996). Ainda se podem obter dados com base em medições da temperatura coletadas no nível do solo. (BARTHOLOMEI, 1998; HEISLER e WANG, 1998; CHEN e WONG, 2006; JOHANSSON e EMMANUEL 2006; HUANG et al., 2008; WONG et al., 2007). Para uma caracterização adequada do conforto térmico, uma das variáveis importantes é a temperatura do ar, que influencia as trocas de calor por convecção sobre o corpo das pessoas.

\section{Metodologia}

Como estratégia de pesquisa, o trabalho levantou e classificou teses, dissertações e artigos acadêmicos, que apresentam em seus conteúdos, combinações dos termos: vegetação, arborização, coberturas verdes, fachadas verdes, ilhas de calor, conforto urbano e clima urbano. A pesquisa foi realizada somente em documentos disponíveis eletronicamente, em sites da internet, através de buscas no Portal de Periódicos da Capes, Portal Google Acadêmico, Portal ResearchGate, repositórios de universidades, sites de congressos, eventos e revistas acadêmicas. Dentre os documentos encontrados e analisados, foram selecionados os documentos resultados de pesquisas com análises quantitativas, que alcançaram 
valores comparativos de temperatura do ar em ambientes externos. Embora o trabalho possa não contemplar toda a produção científica do período, o levantamento serviu para dar um panorama da situação e os principais métodos tratados em cada documento.

Após a seleção, os documentos foram classificados por autor, ano de publicação, tipo de documento, localização das análises e/ou pesquisas, clima, período de análise, tipo de suporte da vegetação, metodologia de análise, e diferença máxima de temperatura encontrada.

O presente trabalho não pretende validar as metodologias adotadas nas pesquisas, mas sim colaborar com o desenvolvimento de pesquisas futuras. Nesse sentido, as diferenças máximas de temperatura destacadas de cada documento são apenas indicativas, já que diferentes metodologias foram adotadas em cada pesquisa.

\section{Análise}

A pesquisa inicial encontrou 161 documentos, que após analisados, resultaram em 87 documentos classificados, sendo: 48 artigos, 25 dissertações e 14 teses. Destes foram extraídas 91 análises da temperatura do ar externo. Na Tabela 1 foram sumarizados todos os documentos selecionados.

Tabela 1: Lista de Documentos Analisados

\begin{tabular}{|c|c|c|c|c|c|c|c|c|}
\hline Documento & Ano & $\begin{array}{c}\text { Tipo de } \\
\text { Documento }\end{array}$ & Localização & $\begin{array}{c}\text { Clima } \\
\text { (Koppen- } \\
\text { Geiger) }\end{array}$ & $\begin{array}{c}\text { Período } \\
\text { de } \\
\text { Análise }\end{array}$ & Vegetação & $\begin{array}{l}\text { Metodologia de } \\
\text { Medição }\end{array}$ & $\begin{array}{l}\text { Diferença de } \\
\text { Temperatura }\end{array}$ \\
\hline Abreu & 2008 & Dissertação & Campinas, SP & $\begin{array}{l}\text { Cfa - Clima } \\
\text { Tropical } \\
\text { Úmido com } \\
\text { Verão Quente }\end{array}$ & $\begin{array}{c}\text { Diurno - } \\
\text { Ano } \\
\text { Inteiro }\end{array}$ & Praças & $\begin{array}{c}\text { Medição em } \\
\text { Campo }\end{array}$ & $1,6^{\circ} \mathrm{C}$ \\
\hline $\begin{array}{c}\text { Albuquerque } \\
\text { et.al. }\end{array}$ & 2016 & Artigo & Teresina, PI & $\begin{array}{c}\text { Aw - Clima } \\
\text { Tropical com } \\
\text { Estação Seca } \\
\text { de Inverno }\end{array}$ & $\begin{array}{c}\text { Diurno e } \\
\text { Noturno - } \\
\text { Verão e } \\
\text { Inverno }\end{array}$ & $\begin{array}{c}\text { Arborização } \\
\text { em vias } \\
\text { urbanas }\end{array}$ & $\begin{array}{l}\text { Medição em } \\
\text { Campo }\end{array}$ & $3,2^{\circ} \mathrm{C}$ \\
\hline $\begin{array}{c}\text { Almeida et. } \\
\text { al. }\end{array}$ & 2015 & Artigo & Maceió, AL & $\begin{array}{l}\text { Am - Clima } \\
\text { de Monção }\end{array}$ & $\begin{array}{c}\text { Diurno - } \\
\text { Verão }\end{array}$ & - & Geoprocessamento & $10,0^{\circ} \mathrm{C}$ \\
\hline Alves & 2016 & Artigo & Iporá, GO & $\begin{array}{c}\text { Aw - Clima } \\
\text { Tropical com } \\
\text { Estação Seca } \\
\text { de Inverno }\end{array}$ & $\begin{array}{l}\text { Diurno e } \\
\text { Noturno - } \\
\text { Inverno }\end{array}$ & Praças & $\begin{array}{c}\text { Medição em } \\
\text { Campo }\end{array}$ & $5,6^{\circ} \mathrm{C}$ \\
\hline Alves et. al. 1 & 2017 & Artigo & Cuiabá, MT & $\begin{array}{c}\text { Aw - Clima } \\
\text { Tropical com } \\
\text { Estação Seca } \\
\text { de Inverno }\end{array}$ & $\begin{array}{c}\text { Diurno - } \\
\text { Ano } \\
\text { Inteiro }\end{array}$ & $\begin{array}{c}\text { Arborização } \\
\text { em vias } \\
\text { urbanas }\end{array}$ & $\begin{array}{c}\text { Medição em } \\
\text { Campo }\end{array}$ & $0,9^{\circ} \mathrm{C}$ \\
\hline Alves et. al. 2 & 2012 & Artigo & $\begin{array}{c}\text { Santa Maria, } \\
\text { RS }\end{array}$ & $\begin{array}{c}\text { Cfa - Clima } \\
\text { Tropical } \\
\text { Úmido com } \\
\text { Verão Quente }\end{array}$ & $\begin{array}{l}\text { Diurno - } \\
\text { Verão }\end{array}$ & $\begin{array}{c}\text { Arborização } \\
\text { em vias } \\
\text { urbanas }\end{array}$ & $\begin{array}{c}\text { Medição em } \\
\text { Campo }\end{array}$ & $3,5^{\circ} \mathrm{C}$ \\
\hline $\begin{array}{c}\text { Amorim et. } \\
\text { al. }\end{array}$ & 2015 & Artigo & $\begin{array}{l}\text { Presidente } \\
\text { Prudente, SP }\end{array}$ & $\begin{array}{c}\text { Aw - Clima } \\
\text { Tropical com } \\
\text { Estação Seca } \\
\text { de Inverno }\end{array}$ & $\begin{array}{l}\text { Diurno - } \\
\text { Inverno }\end{array}$ & - & Geoprocessamento & $3,5^{\circ} \mathrm{C}$ \\
\hline Araujo et. al. & 2016 & Artigo & São Luis, MA & $\begin{array}{c}\text { Aw - Clima } \\
\text { Tropical com } \\
\text { Estação Seca } \\
\text { de Inverno }\end{array}$ & $\begin{array}{l}\text { Diurno - } \\
\text { Primavera }\end{array}$ & Praças & $\begin{array}{c}\text { Medição em } \\
\text { Campo }\end{array}$ & $2,7^{\circ} \mathrm{C}$ \\
\hline Assis et. al. & 2013 & Artigo & $\begin{array}{c}\text { Belo } \\
\text { Horizonte, } \\
\text { MG }\end{array}$ & $\begin{array}{c}\text { Cwb - Clima } \\
\text { Temperado } \\
\text { Úmido com } \\
\text { Inverno Seco } \\
\text { e Verão } \\
\text { Temperado }\end{array}$ & $\begin{array}{l}\text { Diurno e } \\
\text { Noturno - } \\
\text { Verão e } \\
\text { Inverno }\end{array}$ & Praças & $\begin{array}{c}\text { Simulação } \\
\text { Computacional }\end{array}$ & $1,5^{\circ} \mathrm{C}$ \\
\hline $\begin{array}{c}\text { Barbosa et. } \\
\text { al. } 2\end{array}$ & 2010 & Artigo & Campinas, SP & $\begin{array}{c}\text { Cfa - Clima } \\
\text { Tropical } \\
\text { Úmido com } \\
\text { Verão Quente }\end{array}$ & $\begin{array}{l}\text { Diurno - } \\
\text { Inverno }\end{array}$ & Praças & $\begin{array}{l}\text { Medição em } \\
\text { Campo }\end{array}$ & $9,6^{\circ} \mathrm{C}$ \\
\hline Barros & 2016 & Tese & São Paulo, SP & $\begin{array}{c}\text { Cfb - Clima } \\
\text { Tropical } \\
\text { Úmido com }\end{array}$ & $\begin{array}{l}\text { Media Dia } \\
\text { - Ano } \\
\text { Inteiro }\end{array}$ & - & Geoprocessamento & $5,0^{\circ} \mathrm{C}$ \\
\hline
\end{tabular}




\begin{tabular}{|c|c|c|c|c|c|c|c|c|}
\hline & & & & $\begin{array}{c}\text { Verão } \\
\text { Temperado }\end{array}$ & & & & \\
\hline Barros et.al. & 2016 & Artigo & Maceió, AL & $\begin{array}{l}\text { Am - Clima } \\
\text { de Monção }\end{array}$ & $\begin{array}{l}\text { Diurno - } \\
\text { Verão }\end{array}$ & $\begin{array}{c}\text { Arborização } \\
\text { em vias } \\
\text { urbanas } \\
\end{array}$ & $\begin{array}{l}\text { Medição em } \\
\text { Campo }\end{array}$ & $1,1^{\circ} \mathrm{C}$ \\
\hline Barros et.al. & 2016 & Artigo & Maceió, AL & $\begin{array}{l}\text { Am - Clima } \\
\text { de Monção }\end{array}$ & $\begin{array}{l}\text { Diurno - } \\
\text { Verão }\end{array}$ & $\begin{array}{c}\text { Arborização } \\
\text { em vias } \\
\text { urbanas } \\
\end{array}$ & $\begin{array}{c}\text { Simulação } \\
\text { Computacional }\end{array}$ & $1,0^{\circ} \mathrm{C}$ \\
\hline Bezerra & 2013 & Tese & Juazeiro, BA & $\begin{array}{c}\text { As - Clima } \\
\text { Tropical com } \\
\text { Estação Seca } \\
\text { de Verão }\end{array}$ & $\begin{array}{l}\text { Diurno e } \\
\text { Noturno - } \\
\text { Inverno }\end{array}$ & $\begin{array}{c}\text { Arborização } \\
\text { em vias } \\
\text { urbanas }\end{array}$ & $\begin{array}{l}\text { Medição em } \\
\text { Campo }\end{array}$ & $2,0^{\circ} \mathrm{C}$ \\
\hline Bias et. al. & 2003 & Artigo & $\begin{array}{l}\text { Sobradinho, } \\
\text { GO }\end{array}$ & $\begin{array}{c}\text { Aw - Clima } \\
\text { Tropical com } \\
\text { Estação Seca } \\
\text { de Inverno }\end{array}$ & $\begin{array}{l}\text { Diurno - } \\
\text { Inverno }\end{array}$ & - & Geoprocessamento & $4,0^{\circ} \mathrm{C}$ \\
\hline Borges & 2006 & Dissertação & $\begin{array}{l}\text { Florianópolis, } \\
\text { SC }\end{array}$ & $\begin{array}{c}\text { Cfa - Clima } \\
\text { Tropical } \\
\text { Úmido com } \\
\text { Verão Quente }\end{array}$ & $\begin{array}{l}\text { Diurno - } \\
\text { Verão e } \\
\text { Inverno }\end{array}$ & Praças & $\begin{array}{l}\text { Medição em } \\
\text { Campo }\end{array}$ & $3,3^{\circ} \mathrm{C}$ \\
\hline $\begin{array}{l}\text { Brabosa et. } \\
\text { al. } 1\end{array}$ & 2003 & Artigo & Maceió, AL & $\begin{array}{l}\text { Am - Clima } \\
\text { de Monção }\end{array}$ & $\begin{array}{l}\text { Diurno - } \\
\text { Verão }\end{array}$ & $\begin{array}{c}\text { Arborização } \\
\text { em vias } \\
\text { urbanas } \\
\end{array}$ & $\begin{array}{l}\text { Medição em } \\
\text { Campo }\end{array}$ & $2,5^{\circ} \mathrm{C}$ \\
\hline $\begin{array}{c}\text { Callejas et. } \\
\text { al. }\end{array}$ & 2011 & Artigo & $\begin{array}{c}\text { Várzea } \\
\text { Grande, MT }\end{array}$ & $\begin{array}{c}\text { Aw - Clima } \\
\text { Tropical com } \\
\text { Estação Seca } \\
\text { de Inverno }\end{array}$ & $\begin{array}{l}\text { Diurno - } \\
\text { Inverno }\end{array}$ & - & Geoprocessamento & $2,0^{\circ} \mathrm{C}$ \\
\hline Carfan & 2011 & Tese & Ourinhos, SP & $\begin{array}{c}\text { Cfa - Clima } \\
\text { Tropical } \\
\text { Úmido com } \\
\text { Verão Quente }\end{array}$ & $\begin{array}{l}\text { Diurno - } \\
\text { Verão e } \\
\text { Inverno }\end{array}$ & Praças & $\begin{array}{c}\text { Simulação } \\
\text { Computacional }\end{array}$ & $1,4{ }^{\circ} \mathrm{C}$ \\
\hline Carvalho & 2001 & Dissertação & Natal, RN & $\begin{array}{c}\text { As - Clima } \\
\text { Tropical com } \\
\text { Estação Seca } \\
\text { de Verão }\end{array}$ & $\begin{array}{l}\text { Diurno - } \\
\text { Verão }\end{array}$ & Parques & $\begin{array}{l}\text { Medição em } \\
\text { Campo }\end{array}$ & $4,3{ }^{\circ} \mathrm{C}$ \\
\hline $\begin{array}{l}\text { Castelo } \\
\text { Branco }\end{array}$ & 2009 & Dissertação & Brasília, DF & $\begin{array}{c}\text { Aw - Clima } \\
\text { Tropical com } \\
\text { Estação Seca } \\
\text { de Inverno }\end{array}$ & $\begin{array}{l}\text { Diurno - } \\
\text { Verão }\end{array}$ & Praças & $\begin{array}{l}\text { Medição em } \\
\text { Campo }\end{array}$ & $2,8^{\circ} \mathrm{C}$ \\
\hline $\begin{array}{l}\text { Castelo } \\
\text { Branco }\end{array}$ & 2009 & Dissertação & Brasília, DF & $\begin{array}{c}\text { Aw - Clima } \\
\text { Tropical com } \\
\text { Estação Seca } \\
\text { de Inverno }\end{array}$ & $\begin{array}{l}\text { Diurno - } \\
\text { Verão }\end{array}$ & Praças & $\begin{array}{c}\text { Simulação } \\
\text { Computacional }\end{array}$ & $4,9^{\circ} \mathrm{C}$ \\
\hline Castro & 1999 & Dissertação & Campinas, SP & $\begin{array}{c}\text { Cfa - Clima } \\
\text { Tropical } \\
\text { Úmido com } \\
\text { Verão Quente }\end{array}$ & $\begin{array}{l}\text { Diurno - } \\
\text { Verão e } \\
\text { Inverno }\end{array}$ & Parques & $\begin{array}{l}\text { Medição em } \\
\text { Campo }\end{array}$ & $4,0^{\circ} \mathrm{C}$ \\
\hline Catuzzo & 2013 & Tese & São Paulo, SP & $\begin{array}{c}\text { Cfb - Clima } \\
\text { Tropical } \\
\text { Úmido com } \\
\text { Verão } \\
\text { Temperado }\end{array}$ & $\begin{array}{c}\text { Diurno e } \\
\text { Noturno - } \\
\text { Ano } \\
\text { inteiro }\end{array}$ & Coberturas & $\begin{array}{l}\text { Medição em } \\
\text { Campo }\end{array}$ & $6,7^{\circ} \mathrm{C}$ \\
\hline $\begin{array}{l}\text { Cavalcante } \\
\text { et. al. }\end{array}$ & 2005 & Artigo & Maceió, AL & $\begin{array}{l}\text { Am - Clima } \\
\text { de Monção }\end{array}$ & $\begin{array}{l}\text { Diurno - } \\
\text { Verão }\end{array}$ & Praças & $\begin{array}{l}\text { Medição em } \\
\text { Campo }\end{array}$ & $7,7^{\circ} \mathrm{C}$ \\
\hline Costa & 2010 & Artigo & $\begin{array}{l}\text { Ilha Solteira - } \\
\text { SP }\end{array}$ & $\begin{array}{c}\text { Aw - Clima } \\
\text { Tropical com } \\
\text { Estação Seca } \\
\text { de Inverno }\end{array}$ & $\begin{array}{l}\text { Diurno - } \\
\text { Verão }\end{array}$ & - & Geoprocessamento & $3,0^{\circ} \mathrm{C}$ \\
\hline De Zorzi & 2016 & Dissertação & $\begin{array}{c}\text { Porto Alegre, } \\
\text { RS }\end{array}$ & $\begin{array}{c}\text { Cfa - Clima } \\
\text { Tropical } \\
\text { Úmido com } \\
\text { Verão Quente }\end{array}$ & $\begin{array}{c}\text { Diurno - } \\
\text { Ano } \\
\text { inteiro }\end{array}$ & Parques & $\begin{array}{l}\text { Medição em } \\
\text { Campo }\end{array}$ & $2,3^{\circ} \mathrm{C}$ \\
\hline Diniz Júnior & 2012 & Dissertação & Santarém, PA & $\begin{array}{l}\text { Am - Clima } \\
\text { de Monção }\end{array}$ & $\begin{array}{c}\text { Diurno e } \\
\text { Noturno - } \\
\text { Verão e } \\
\text { Inverno } \\
\end{array}$ & Praças & $\begin{array}{l}\text { Medição em } \\
\text { Campo }\end{array}$ & $2,0^{\circ} \mathrm{C}$ \\
\hline Dobbert & 2015 & Tese & Campinas, SP & $\begin{array}{c}\text { Cfa - Clima } \\
\text { Tropical } \\
\text { Úmido com } \\
\text { Verão Quente }\end{array}$ & $\begin{array}{l}\text { Diurno e } \\
\text { Noturno - } \\
\text { Verão }\end{array}$ & Praças & $\begin{array}{c}\text { Simulação } \\
\text { Computacional }\end{array}$ & $2,5^{\circ} \mathrm{C}$ \\
\hline
\end{tabular}




\begin{tabular}{|c|c|c|c|c|c|c|c|c|}
\hline Duarte 1 & 2007 & Artigo & São Paulo, SP & $\begin{array}{l}\text { Cfb - Clima } \\
\text { Tropical } \\
\text { Úmido com } \\
\text { Verão } \\
\text { Temperado }\end{array}$ & $\begin{array}{l}\text { Diurno - } \\
\text { Verão }\end{array}$ & Parques & $\begin{array}{l}\text { Medição em } \\
\text { Campo }\end{array}$ & $5,0^{\circ} \mathrm{C}$ \\
\hline Duarte 2 & 2000 & Tese & Cuiabá, MT & $\begin{array}{l}\text { Aw - Clima } \\
\text { Tropical com } \\
\text { Estação Seca } \\
\text { de Inverno }\end{array}$ & $\begin{array}{l}\text { Diurno - } \\
\text { Verão e } \\
\text { Inverno }\end{array}$ & Parques & $\begin{array}{l}\text { Medição em } \\
\text { Campo }\end{array}$ & $5,7^{\circ} \mathrm{C}$ \\
\hline Duarte 3 & 2015 & Tese & São Paulo, SP & $\begin{array}{l}\text { Cfb - Clima } \\
\text { Tropical } \\
\text { Úmido com } \\
\text { Verão } \\
\text { Temperado }\end{array}$ & $\begin{array}{l}\text { Diurno - } \\
\text { Verão e } \\
\text { Outono }\end{array}$ & Parques & $\begin{array}{c}\text { Simulação } \\
\text { Computacional }\end{array}$ & $1,5^{\circ} \mathrm{C}$ \\
\hline Elsing & 2016 & Dissertação & São Paulo, SP & $\begin{array}{l}\text { Cfb - Clima } \\
\text { Tropical } \\
\text { Úmido com } \\
\text { Verão } \\
\text { Temperado }\end{array}$ & $\begin{array}{l}\text { Diurno - } \\
\text { Verão }\end{array}$ & $\begin{array}{c}\text { Arborização } \\
\text { em vias } \\
\text { urbanas }\end{array}$ & $\begin{array}{c}\text { Simulação } \\
\text { Computacional }\end{array}$ & $0,2^{\circ} \mathrm{C}$ \\
\hline Ferreira & 2012 & Artigo & $\begin{array}{l}\text { Juiz de Fora, } \\
\text { MG }\end{array}$ & $\begin{array}{l}\text { Cwb - Clima } \\
\text { Temperado } \\
\text { Úmido com } \\
\text { Inverno Seco } \\
\text { e Verão } \\
\text { Temperado }\end{array}$ & $\begin{array}{l}\text { Diurno - } \\
\text { Inverno }\end{array}$ & Praças & $\begin{array}{l}\text { Medição em } \\
\text { Campo }\end{array}$ & $7,6^{\circ} \mathrm{C}$ \\
\hline $\begin{array}{l}\text { Frederico e } \\
\text { Silva }\end{array}$ & 2009 & Dissertação & Teresina, PI & $\begin{array}{l}\text { Aw - Clima } \\
\text { Tropical com } \\
\text { Estação Seca } \\
\text { de Inverno }\end{array}$ & $\begin{array}{l}\text { Diurno - } \\
\text { Verão e } \\
\text { Inverno }\end{array}$ & $\begin{array}{c}\text { Arborização } \\
\text { em vias } \\
\text { urbanas }\end{array}$ & $\begin{array}{l}\text { Medição em } \\
\text { Campo }\end{array}$ & $1,7^{\circ} \mathrm{C}$ \\
\hline $\begin{array}{l}\text { Frederico e } \\
\text { Silva }\end{array}$ & 2009 & Dissertação & Teresina, PI & $\begin{array}{l}\text { Aw - Clima } \\
\text { Tropical com } \\
\text { Estação Seca } \\
\text { de Inverno }\end{array}$ & $\begin{array}{l}\text { Diurno - } \\
\text { Verão e } \\
\text { Inverno }\end{array}$ & $\begin{array}{c}\text { Arborização } \\
\text { em vias } \\
\text { urbanas }\end{array}$ & $\begin{array}{c}\text { Simulação } \\
\text { Computacional }\end{array}$ & $3,1^{\circ} \mathrm{C}$ \\
\hline Gallo et. al. & 2013 & Artigo & Campinas, SP & $\begin{array}{c}\text { Cfa - Clima } \\
\text { Tropical } \\
\text { Úmido com } \\
\text { Verão Quente }\end{array}$ & $\begin{array}{l}\text { Diurno - } \\
\text { Primavera }\end{array}$ & - & Geoprocessamento & $5,0^{\circ} \mathrm{C}$ \\
\hline Gomes et. al. & 2003 & Artigo & $\begin{array}{l}\text { Presidente } \\
\text { Prudente, SP }\end{array}$ & $\begin{array}{c}\text { Aw - Clima } \\
\text { Tropical com } \\
\text { Estação Seca } \\
\text { de Inverno }\end{array}$ & $\begin{array}{l}\text { Diurno e } \\
\text { Noturno - } \\
\text { Verão }\end{array}$ & Praças & $\begin{array}{l}\text { Medição em } \\
\text { Campo }\end{array}$ & $1,2^{\circ} \mathrm{C}$ \\
\hline $\begin{array}{l}\text { Gonçalves et. } \\
\text { al. }\end{array}$ & 2012 & Artigo & Maringá, PR & $\begin{array}{c}\text { Cfa - Clima } \\
\text { Tropical } \\
\text { Úmido com } \\
\text { Verão Quente }\end{array}$ & $\begin{array}{l}\text { Diurno - } \\
\text { Verão }\end{array}$ & $\begin{array}{c}\text { Arborização } \\
\text { em vias } \\
\text { urbanas }\end{array}$ & $\begin{array}{l}\text { Medição em } \\
\text { Campo }\end{array}$ & $1,6^{\circ} \mathrm{C}$ \\
\hline Heerdt et.al. & 2017 & Artigo & Brasília, DF & $\begin{array}{l}\text { Aw - Clima } \\
\text { Tropical com } \\
\text { Estação Seca } \\
\text { de Inverno }\end{array}$ & $\begin{array}{l}\text { Diurno - } \\
\text { Verão e } \\
\text { Inverno }\end{array}$ & Praças & $\begin{array}{c}\text { Simulação } \\
\text { Computacional }\end{array}$ & $2,5^{\circ} \mathrm{C}$ \\
\hline $\begin{array}{c}\text { Junior et. al. } \\
1\end{array}$ & 2013 & Artigo & Santarém, PA & $\begin{array}{l}\text { Am - Clima } \\
\text { de Monção }\end{array}$ & $\begin{array}{c}\text { Diurno e } \\
\text { Noturno - } \\
\text { Outono } \\
\end{array}$ & Praças & $\begin{array}{l}\text { Medição em } \\
\text { Campo }\end{array}$ & $1,0^{\circ} \mathrm{C}$ \\
\hline $\begin{array}{c}\text { Junior et. al. } \\
\qquad 2\end{array}$ & 2016 & Artigo & Marabá, PA & $\begin{array}{l}\text { Am - Clima } \\
\text { de Monção }\end{array}$ & $\begin{array}{l}\text { Diurno - } \\
\text { Inverno }\end{array}$ & $\begin{array}{c}\text { Arborização } \\
\text { em vias } \\
\text { urbanas }\end{array}$ & $\begin{array}{l}\text { Medição em } \\
\text { Campo }\end{array}$ & $2,5^{\circ} \mathrm{C}$ \\
\hline $\begin{array}{c}\text { Junior et. al. } \\
3\end{array}$ & 2014 & Artigo & Curitiba, PR & $\begin{array}{l}\text { Cfb - Clima } \\
\text { Tropical } \\
\text { Úmido com } \\
\text { Verão } \\
\text { Temperado } \\
\end{array}$ & $\begin{array}{l}\text { Diurno - } \\
\text { Inverno }\end{array}$ & $\begin{array}{c}\text { Arborização } \\
\text { em vias } \\
\text { urbanas }\end{array}$ & $\begin{array}{l}\text { Medição em } \\
\text { Campo }\end{array}$ & $4,1^{\circ} \mathrm{C}$ \\
\hline Kruger et. al. & 2008 & Artigo & Curitiba, PR & $\begin{array}{l}\text { Cfb - Clima } \\
\text { Tropical } \\
\text { Úmido com } \\
\text { Verão } \\
\text { Temperado }\end{array}$ & $\begin{array}{l}\text { Diurno - } \\
\text { Outono }\end{array}$ & Parques & $\begin{array}{l}\text { Medição em } \\
\text { Campo }\end{array}$ & $1,6^{\circ} \mathrm{C}$ \\
\hline Leal & 2014 & Artigo & Curitiba, PR & $\begin{array}{l}\text { Cfb - Clima } \\
\text { Tropical } \\
\text { Úmido com } \\
\text { Verão } \\
\text { Temperado }\end{array}$ & $\begin{array}{c}\text { Diurno e } \\
\text { Noturno - } \\
\text { Ano } \\
\text { inteiro }\end{array}$ & Parques & $\begin{array}{l}\text { Medição em } \\
\text { Campo }\end{array}$ & $1,7^{\circ} \mathrm{C}$ \\
\hline Leal et.al. & 2014 & Artigo & Curitiba, PR & $\begin{array}{l}\text { Cfb - Clima } \\
\text { Tropical } \\
\text { Úmido com }\end{array}$ & $\begin{array}{l}\text { Diurno e } \\
\text { Noturno - }\end{array}$ & $\begin{array}{c}\text { Arborização } \\
\text { em vias } \\
\text { urbanas } \\
\end{array}$ & $\begin{array}{l}\text { Medição em } \\
\text { Campo }\end{array}$ & $5,8^{\circ} \mathrm{C}$ \\
\hline
\end{tabular}




\begin{tabular}{|c|c|c|c|c|c|c|c|c|}
\hline & & & & $\begin{array}{c}\text { Verão } \\
\text { Temperado }\end{array}$ & $\begin{array}{c}\text { Ano } \\
\text { inteiro }\end{array}$ & & & \\
\hline Lima et. al. & 2009 & Artigo & Maringá, PR & $\begin{array}{c}\text { Cfa - Clima } \\
\text { Tropical } \\
\text { Úmido com } \\
\text { Verão Quente }\end{array}$ & $\begin{array}{l}\text { Diurno - } \\
\text { Verão }\end{array}$ & Praças & $\begin{array}{l}\text { Medição em } \\
\text { Campo }\end{array}$ & $2,8^{\circ} \mathrm{C}$ \\
\hline Lucena & 2012 & Tese & $\begin{array}{c}\text { Rio de } \\
\text { Janeiro, RJ }\end{array}$ & $\begin{array}{l}\text { Am - Clima } \\
\text { de Monção }\end{array}$ & $\begin{array}{l}\text { Media Dia } \\
\text { - Ano } \\
\text { Inteiro } \\
\end{array}$ & - & Geoprocessamento & $7,5^{\circ} \mathrm{C}$ \\
\hline Maciel & 2014 & Tese & Cuiabá, MT & $\begin{array}{l}\text { Aw - Clima } \\
\text { Tropical com } \\
\text { Estação Seca } \\
\text { de Inverno }\end{array}$ & $\begin{array}{l}\text { Diurno - } \\
\text { Verão e } \\
\text { Inverno }\end{array}$ & Coberturas & $\begin{array}{c}\text { Simulação } \\
\text { Computacional }\end{array}$ & $0,7^{\circ} \mathrm{C}$ \\
\hline Malentachi & 2013 & Dissertação & Uruaçu, GO & $\begin{array}{l}\text { Aw - Clima } \\
\text { Tropical com } \\
\text { Estação Seca } \\
\text { de Inverno }\end{array}$ & $\begin{array}{l}\text { Diurno - } \\
\text { Inverno }\end{array}$ & $\begin{array}{c}\text { Arborização } \\
\text { em vias } \\
\text { urbanas }\end{array}$ & $\begin{array}{l}\text { Medição em } \\
\text { Campo }\end{array}$ & $4,0^{\circ} \mathrm{C}$ \\
\hline Marra et. a. & 2017 & Artigo & $\begin{array}{c}\text { Belo } \\
\text { Horizonte, } \\
\text { MG }\end{array}$ & $\begin{array}{l}\text { Cwb - Clima } \\
\text { Temperado } \\
\text { Úmido com } \\
\text { Inverno Seco } \\
\text { e Verão } \\
\text { Temperado } \\
\end{array}$ & $\begin{array}{l}\text { Diurno e } \\
\text { Noturno - } \\
\text { Verão }\end{array}$ & $\begin{array}{c}\text { Arborização } \\
\text { em vias } \\
\text { urbanas }\end{array}$ & $\begin{array}{c}\text { Simulação } \\
\text { Computacional }\end{array}$ & $3,5^{\circ} \mathrm{C}$ \\
\hline Martini & 2013 & Dissertação & Curitiba, PR & $\begin{array}{c}\text { Cfb - Clima } \\
\text { Tropical } \\
\text { Úmido com } \\
\text { Verão } \\
\text { Temperado } \\
\end{array}$ & $\begin{array}{l}\text { Diurno - } \\
\text { Ano } \\
\text { Inteiro }\end{array}$ & $\begin{array}{c}\text { Arborização } \\
\text { em vias } \\
\text { urbanas }\end{array}$ & $\begin{array}{l}\text { Medição em } \\
\text { Campo }\end{array}$ & $2,5^{\circ} \mathrm{C}$ \\
\hline $\begin{array}{l}\text { Martini et. } \\
\text { al. }\end{array}$ & 2014 & Artigo & Curitiba, PR & $\begin{array}{c}\text { Cfb - Clima } \\
\text { Tropical } \\
\text { Úmido com } \\
\text { Verão } \\
\text { Temperado }\end{array}$ & $\begin{array}{l}\text { Diurno - } \\
\text { Ano } \\
\text { Inteiro }\end{array}$ & $\begin{array}{c}\text { Arborização } \\
\text { em vias } \\
\text { urbanas }\end{array}$ & $\begin{array}{l}\text { Medição em } \\
\text { Campo }\end{array}$ & $6,6^{\circ} \mathrm{C}$ \\
\hline $\begin{array}{l}\text { Mascarello } \\
\text { et. al. }\end{array}$ & 2017 & Artigo & $\begin{array}{c}\text { Pará de } \\
\text { Minas, MG }\end{array}$ & $\begin{array}{l}\text { Cwa - Clima } \\
\text { Temperado } \\
\text { Úmido com } \\
\text { Inverno Seco } \\
\text { e Verão } \\
\text { Quente }\end{array}$ & $\begin{array}{l}\text { Diurno - } \\
\text { Inverno }\end{array}$ & $\begin{array}{c}\text { Arborização } \\
\text { em vias } \\
\text { urbanas }\end{array}$ & $\begin{array}{l}\text { Medição em } \\
\text { Campo }\end{array}$ & $4,5^{\circ} \mathrm{C}$ \\
\hline Mashiki & 2012 & Dissertação & Botucatu, SP & $\begin{array}{c}\text { Cfa - Clima } \\
\text { Tropical } \\
\text { Úmido com } \\
\text { Verão Quente }\end{array}$ & $\begin{array}{l}\text { Media Dia } \\
\text { - Verão }\end{array}$ & - & Geoprocessamento & $4,0^{\circ} \mathrm{C}$ \\
\hline Minella & 2014 & Tese & Curitiba, PR & $\begin{array}{c}\text { Cfb - Clima } \\
\text { Tropical } \\
\text { Úmido com } \\
\text { Verão } \\
\text { Temperado } \\
\end{array}$ & $\begin{array}{l}\text { Diurno - } \\
\text { Verão }\end{array}$ & $\begin{array}{c}\text { Arborização } \\
\text { em vias } \\
\text { urbanas }\end{array}$ & $\begin{array}{c}\text { Simulação } \\
\text { Computacional }\end{array}$ & $1,5^{\circ} \mathrm{C}$ \\
\hline Minella et.al. & 2011 & Artigo & São Paulo, SP & $\begin{array}{c}\text { Cfb - Clima } \\
\text { Tropical } \\
\text { Úmido com } \\
\text { Verão } \\
\text { Temperado } \\
\end{array}$ & $\begin{array}{l}\text { Diurno - } \\
\text { Verão }\end{array}$ & $\begin{array}{c}\text { Arborização } \\
\text { em vias } \\
\text { urbanas }\end{array}$ & $\begin{array}{l}\text { Medição em } \\
\text { Campo }\end{array}$ & $3,2^{\circ} \mathrm{C}$ \\
\hline Minella et.al. & 2011 & Artigo & São Paulo, SP & $\begin{array}{c}\text { Cfb - Clima } \\
\text { Tropical } \\
\text { Úmido com } \\
\text { Verão } \\
\text { Temperado }\end{array}$ & $\begin{array}{l}\text { Diurno - } \\
\text { Verão }\end{array}$ & $\begin{array}{c}\text { Arborização } \\
\text { em vias } \\
\text { urbanas }\end{array}$ & $\begin{array}{c}\text { Simulação } \\
\text { Computacional }\end{array}$ & $1,8^{\circ} \mathrm{C}$ \\
\hline Morais et. al. & 2014 & Artigo & São Paulo, SP & $\begin{array}{c}\text { Cfb - Clima } \\
\text { Tropical } \\
\text { Úmido com } \\
\text { Verão } \\
\text { Temperado } \\
\end{array}$ & $\begin{array}{l}\text { Diurno - } \\
\text { Inverno }\end{array}$ & - & Geoprocessamento & $2,0^{\circ} \mathrm{C}$ \\
\hline Nince et. al. & 2014 & Artigo & Cuiabá, MT & $\begin{array}{l}\text { Aw - Clima } \\
\text { Tropical com } \\
\text { Estação Seca } \\
\text { de Inverno }\end{array}$ & $\begin{array}{l}\text { Diurno - } \\
\text { Verão e } \\
\text { Inverno }\end{array}$ & $\begin{array}{c}\text { Arborização } \\
\text { em vias } \\
\text { urbanas }\end{array}$ & $\begin{array}{l}\text { Medição em } \\
\text { Campo }\end{array}$ & $4,2^{\circ} \mathrm{C}$ \\
\hline Oliveira & 2015 & Dissertação & Vila Velha, ES & $\begin{array}{l}\text { Am - Clima } \\
\text { de Monção }\end{array}$ & $\begin{array}{c}\text { Diurno - } \\
\text { Ano } \\
\text { inteiro } \\
\end{array}$ & - & Geoprocessamento & $7,2^{\circ} \mathrm{C}$ \\
\hline
\end{tabular}




\begin{tabular}{|c|c|c|c|c|c|c|c|c|}
\hline $\begin{array}{l}\text { Oliveira et. } \\
\text { al }\end{array}$ & 2013 & Artigo & Iporá, GO & $\begin{array}{c}\text { Aw - Clima } \\
\text { Tropical com } \\
\text { Estação Seca } \\
\text { de Inverno }\end{array}$ & $\begin{array}{l}\text { Diurno e } \\
\text { Noturno - } \\
\text { Inverno }\end{array}$ & Praças & $\begin{array}{l}\text { Medição em } \\
\text { Campo }\end{array}$ & $6,3^{\circ} \mathrm{C}$ \\
\hline Pastro et.al. & 2012 & Artigo & Brasília, DF & $\begin{array}{c}\text { Aw - Clima } \\
\text { Tropical com } \\
\text { Estação Seca } \\
\text { de Inverno }\end{array}$ & $\begin{array}{l}\text { Diurno - } \\
\text { Inverno }\end{array}$ & Praças & $\begin{array}{c}\text { Simulação } \\
\text { Computacional }\end{array}$ & $4,2{ }^{\circ} \mathrm{C}$ \\
\hline Paz & 2009 & Dissertação & Palmas, T0 & $\begin{array}{c}\text { Aw - Clima } \\
\text { Tropical com } \\
\text { Estação Seca } \\
\text { de Inverno }\end{array}$ & $\begin{array}{l}\text { Noturno - } \\
\text { Primavera }\end{array}$ & $\begin{array}{c}\text { Arborização } \\
\text { em vias } \\
\text { urbanas }\end{array}$ & $\begin{array}{l}\text { Medição em } \\
\text { Campo }\end{array}$ & $4,1^{\circ} \mathrm{C}$ \\
\hline $\begin{array}{l}\text { Pezzuto et. } \\
\text { al. }\end{array}$ & 2015 & Artigo & Campinas, SP & $\begin{array}{c}\text { Cfa - Clima } \\
\text { Tropical } \\
\text { Úmido com } \\
\text { Verão Quente }\end{array}$ & $\begin{array}{l}\text { Diurno e } \\
\text { Noturno - } \\
\text { Verão }\end{array}$ & $\begin{array}{c}\text { Arborização } \\
\text { em vias } \\
\text { urbanas }\end{array}$ & $\begin{array}{c}\text { Simulação } \\
\text { Computacional }\end{array}$ & $4,0^{\circ} \mathrm{C}$ \\
\hline Rafael & 2014 & Dissertação & Manaus, AM & $\begin{array}{c}\text { Af - Clima } \\
\text { Tropical } \\
\text { Úmido }\end{array}$ & $\begin{array}{c}\text { Diurno e } \\
\text { Noturno - } \\
\text { Outono }\end{array}$ & - & Geoprocessamento & $8,8^{\circ} \mathrm{C}$ \\
\hline Ramaldes & 2015 & Dissertação & Vitória, ES & $\begin{array}{l}\text { Am - Clima } \\
\text { de Monção }\end{array}$ & $\begin{array}{l}\text { Diurno - } \\
\text { Verão }\end{array}$ & $\begin{array}{c}\text { Arborização } \\
\text { em vias } \\
\text { urbanas }\end{array}$ & $\begin{array}{l}\text { Medição em } \\
\text { Campo }\end{array}$ & $5,6^{\circ} \mathrm{C}$ \\
\hline Reis & 2014 & Dissertação & $\begin{array}{c}\text { Piracicaba, } \\
\text { SP }\end{array}$ & $\begin{array}{c}\text { Cfa - Clima } \\
\text { Tropical } \\
\text { Úmido com } \\
\text { Verão Quente }\end{array}$ & $\begin{array}{l}\text { Diurno - } \\
\text { Verão e } \\
\text { Inverno }\end{array}$ & Parques & $\begin{array}{l}\text { Medição em } \\
\text { Campo }\end{array}$ & $1,8^{\circ} \mathrm{C}$ \\
\hline $\begin{array}{c}\text { Rocha et. al. } \\
1\end{array}$ & 2010 & Artigo & Viçosa - MG & $\begin{array}{l}\text { Cwa - Clima } \\
\text { Temperado } \\
\text { Úmido com } \\
\text { Inverno Seco } \\
\text { e Verão } \\
\text { Quente }\end{array}$ & $\begin{array}{l}\text { Diurno - } \\
\text { Inverno }\end{array}$ & $\begin{array}{c}\text { Arborização } \\
\text { em vias } \\
\text { urbanas }\end{array}$ & $\begin{array}{l}\text { Medição em } \\
\text { Campo }\end{array}$ & $2,3^{\circ} \mathrm{C}$ \\
\hline $\begin{array}{c}\text { Rocha et. al. } \\
2\end{array}$ & 2011 & Artigo & $\begin{array}{l}\text { São José do } \\
\text { Rio Preto, SP }\end{array}$ & $\begin{array}{l}\text { Aw - Clima } \\
\text { Tropical com } \\
\text { Estação Seca } \\
\text { de Inverno }\end{array}$ & $\begin{array}{l}\text { Diurno - } \\
\text { Outono }\end{array}$ & $\begin{array}{c}\text { Arborização } \\
\text { em vias } \\
\text { urbanas }\end{array}$ & $\begin{array}{l}\text { Medição em } \\
\text { Campo }\end{array}$ & $1,5^{\circ} \mathrm{C}$ \\
\hline Da Costa & 2015 & Tese & Chapecó, SC & $\begin{array}{c}\text { Cfa - Clima } \\
\text { Tropical } \\
\text { Úmido com } \\
\text { Verão Quente }\end{array}$ & $\begin{array}{c}\text { Diurno e } \\
\text { Noturno - } \\
\text { Ano } \\
\text { inteiro }\end{array}$ & $\begin{array}{c}\text { Arborização } \\
\text { em vias } \\
\text { urbanas }\end{array}$ & $\begin{array}{l}\text { Medição em } \\
\text { Campo }\end{array}$ & $3,0^{\circ} \mathrm{C}$ \\
\hline Rodrigues & 2017 & Tese & Belém, PA & $\begin{array}{c}\text { As - Clima } \\
\text { Tropical com } \\
\text { Estação Seca } \\
\text { de Verão }\end{array}$ & $\begin{array}{c}\text { Diurno e } \\
\text { Noturno - } \\
\text { Ano } \\
\text { Inteiro }\end{array}$ & $\begin{array}{c}\text { Arborização } \\
\text { em vias } \\
\text { urbanas }\end{array}$ & $\begin{array}{l}\text { Medição em } \\
\text { Campo }\end{array}$ & $2,2^{\circ} \mathrm{C}$ \\
\hline Rosseti & 2013 & Tese & Cuiabá, MT & $\begin{array}{l}\text { Aw - Clima } \\
\text { Tropical com } \\
\text { Estação Seca } \\
\text { de Inverno }\end{array}$ & $\begin{array}{l}\text { Diurno - } \\
\text { Verão e } \\
\text { Inverno }\end{array}$ & Coberturas & $\begin{array}{c}\text { Simulação } \\
\text { Computacional }\end{array}$ & $1,6^{\circ} \mathrm{C}$ \\
\hline Rosseti et. al. & 2011 & Artigo & Cuiabá, MT & $\begin{array}{c}\text { Aw - Clima } \\
\text { Tropical com } \\
\text { Estação Seca } \\
\text { de Inverno }\end{array}$ & $\begin{array}{l}\text { Diurno - } \\
\text { Verão e } \\
\text { Inverno }\end{array}$ & Coberturas & $\begin{array}{l}\text { Medição em } \\
\text { Campo }\end{array}$ & $2,6^{\circ} \mathrm{C}$ \\
\hline Sarka & 2016 & Dissertação & $\begin{array}{c}\text { Rio de } \\
\text { Janeiro, RJ }\end{array}$ & $\begin{array}{l}\text { Am - Clima } \\
\text { de Monção }\end{array}$ & $\begin{array}{l}\text { Diurno e } \\
\text { Noturno - } \\
\text { Verão e } \\
\text { Inverno } \\
\end{array}$ & Coberturas & $\begin{array}{l}\text { Medição em } \\
\text { Campo }\end{array}$ & $1,2^{\circ} \mathrm{C}$ \\
\hline Sena et. al. & 2014 & Artigo & $\begin{array}{c}\text { Rio de } \\
\text { Janeiro, RJ }\end{array}$ & $\begin{array}{l}\text { Am - Clima } \\
\text { de Monção }\end{array}$ & $\begin{array}{c}\text { Diurno - } \\
\text { Ano } \\
\text { Inteiro }\end{array}$ & - & Geoprocessamento & $10,0^{\circ} \mathrm{C}$ \\
\hline Shinzato & 2009 & Dissertação & São Paulo, SP & $\begin{array}{c}\text { Cfb - Clima } \\
\text { Tropical } \\
\text { Úmido com } \\
\text { Verão } \\
\text { Temperado }\end{array}$ & $\begin{array}{l}\text { Diurno - } \\
\text { Outono }\end{array}$ & Praças & $\begin{array}{c}\text { Simulação } \\
\text { Computacional }\end{array}$ & $3,0^{\circ} \mathrm{C}$ \\
\hline Shinzato & 2014 & Tese & São Paulo, SP & $\begin{array}{l}\text { Cfb - Clima } \\
\text { Tropical } \\
\text { Úmido com } \\
\text { Verão } \\
\text { Temperado }\end{array}$ & $\begin{array}{c}\text { Diurno - } \\
\text { Primavera }\end{array}$ & Parques & $\begin{array}{c}\text { Simulação } \\
\text { Computacional }\end{array}$ & $1,0^{\circ} \mathrm{C}$ \\
\hline $\begin{array}{l}\text { Shinzato et. } \\
\text { al. }\end{array}$ & 2011 & Artigo & São Paulo, SP & $\begin{array}{c}\text { Cfb - Clima } \\
\text { Tropical } \\
\text { Úmido com }\end{array}$ & $\begin{array}{l}\text { Diurno - } \\
\text { Verão }\end{array}$ & Praças & $\begin{array}{l}\text { Medição em } \\
\text { Campo }\end{array}$ & $2,9^{\circ} \mathrm{C}$ \\
\hline
\end{tabular}




\begin{tabular}{|c|c|c|c|c|c|c|c|c|}
\hline & & & & $\begin{array}{c}\text { Verão } \\
\text { Temperado }\end{array}$ & & & & \\
\hline $\begin{array}{c}\text { Shinzato et. } \\
\text { al. }\end{array}$ & 2011 & Artigo & São Paulo, SP & $\begin{array}{l}\text { Cfb - Clima } \\
\text { Tropical } \\
\text { Úmido com } \\
\text { Verão } \\
\text { Temperado }\end{array}$ & $\begin{array}{l}\text { Diurno - } \\
\text { Verão }\end{array}$ & Praças & $\begin{array}{c}\text { Simulação } \\
\text { Computacional }\end{array}$ & $1,4^{\circ} \mathrm{C}$ \\
\hline Silva et. al. & 2015 & Artigo & Vitória, ES & $\begin{array}{l}\text { Am - Clima } \\
\text { de Monção }\end{array}$ & $\begin{array}{c}\text { Diurno - } \\
\text { Verão }\end{array}$ & Parques & $\begin{array}{c}\text { Medição em } \\
\text { Campo }\end{array}$ & $3,0^{\circ} \mathrm{C}$ \\
\hline Sorte & 2016 & Dissertação & Brasília, DF & $\begin{array}{c}\text { Aw - Clima } \\
\text { Tropical com } \\
\text { Estação Seca } \\
\text { de Inverno }\end{array}$ & $\begin{array}{c}\text { Diurno e } \\
\text { Noturno - } \\
\text { Primavera }\end{array}$ & $\begin{array}{l}\text { Fachadas } \\
\text { de } \\
\text { Edificações }\end{array}$ & $\begin{array}{c}\text { Simulação } \\
\text { Computacional }\end{array}$ & $1,0^{\circ} \mathrm{C}$ \\
\hline Sousa et. al. & 2012 & Artigo & Curitiba, PR & $\begin{array}{c}\text { Cfb - Clima } \\
\text { Tropical } \\
\text { Úmido com } \\
\text { Verão } \\
\text { Temperado }\end{array}$ & $\begin{array}{l}\text { Diurno - } \\
\text { Inverno }\end{array}$ & - & Geoprocessamento & $8,0^{\circ} \mathrm{C}$ \\
\hline Souza 1 & 2016 & Dissertação & $\begin{array}{c}\text { Campo } \\
\text { Grande, MS }\end{array}$ & $\begin{array}{l}\text { Am - Clima } \\
\text { de Monção }\end{array}$ & $\begin{array}{l}\text { Noturno - } \\
\text { Verão e } \\
\text { Inverno } \\
\end{array}$ & $\begin{array}{c}\text { Arborização } \\
\text { em vias } \\
\text { urbanas } \\
\end{array}$ & $\begin{array}{l}\text { Medição em } \\
\text { Campo }\end{array}$ & $3,0^{\circ} \mathrm{C}$ \\
\hline Souza 2 & 2011 & Dissertação & Vitória, ES & $\begin{array}{l}\text { Am - Clima } \\
\text { de Monção }\end{array}$ & $\begin{array}{l}\text { Diurno - } \\
\text { Verão }\end{array}$ & Praças & $\begin{array}{c}\text { Medição em } \\
\text { Campo }\end{array}$ & $3,4^{\circ} \mathrm{C}$ \\
\hline $\begin{array}{c}\text { Teixeira et. } \\
\text { al. }\end{array}$ & 2014 & Artigo & $\begin{array}{c}\text { Belo } \\
\text { Horizonte, } \\
\text { MG }\end{array}$ & $\begin{array}{l}\text { Cwb - Clima } \\
\text { Temperado } \\
\text { Úmido com } \\
\text { Inverno Seco } \\
\text { e Verão } \\
\text { Temperado }\end{array}$ & $\begin{array}{l}\text { Diurno - } \\
\text { Outono }\end{array}$ & $\begin{array}{c}\text { Arborização } \\
\text { em vias } \\
\text { urbanas }\end{array}$ & $\begin{array}{l}\text { Medição em } \\
\text { Campo }\end{array}$ & $5,0^{\circ} \mathrm{C}$ \\
\hline Vasconcellos & 2006 & Tese & $\begin{array}{c}\text { Rio de } \\
\text { Janeiro, RJ }\end{array}$ & $\begin{array}{l}\text { Am - Clima } \\
\text { de Monção }\end{array}$ & $\begin{array}{l}\text { Diurno - } \\
\text { Verão e } \\
\text { Inverno }\end{array}$ & Praças & $\begin{array}{l}\text { Medição em } \\
\text { Campo }\end{array}$ & $2,3^{\circ} \mathrm{C}$ \\
\hline Vasconcelos & 2014 & Dissertação & $\begin{array}{c}\text { São Carlos, } \\
\text { SP }\end{array}$ & $\begin{array}{c}\text { Cwa - Clima } \\
\text { Temperado } \\
\text { Úmido com } \\
\text { Inverno Seco } \\
\text { e Verão } \\
\text { Quente }\end{array}$ & $\begin{array}{l}\text { Diurno - } \\
\text { Inverno }\end{array}$ & $\begin{array}{c}\text { Arborização } \\
\text { em vias } \\
\text { urbanas }\end{array}$ & $\begin{array}{c}\text { Simulação } \\
\text { Computacional }\end{array}$ & $0,9^{\circ} \mathrm{C}$ \\
\hline Vieira et. al. & 2015 & Artigo & Campinas, SP & $\begin{array}{c}\text { Cfa - Clima } \\
\text { Tropical } \\
\text { Úmido com } \\
\text { Verão Quente }\end{array}$ & $\begin{array}{l}\text { Diurno e } \\
\text { Noturno - } \\
\text { Verão }\end{array}$ & $\begin{array}{c}\text { Arborização } \\
\text { em vias } \\
\text { urbanas }\end{array}$ & $\begin{array}{c}\text { Simulação } \\
\text { Computacional }\end{array}$ & $2,7^{\circ} \mathrm{C}$ \\
\hline Xavier et. al. & 2009 & Artigo & Cuiabá, MT & $\begin{array}{c}\text { Aw - Clima } \\
\text { Tropical com } \\
\text { Estação Seca } \\
\text { de Inverno }\end{array}$ & $\begin{array}{c}\text { Diurno e } \\
\text { Noturno - } \\
\text { Primavera }\end{array}$ & $\begin{array}{c}\text { Arborização } \\
\text { em vias } \\
\text { urbanas }\end{array}$ & $\begin{array}{l}\text { Medição em } \\
\text { Campo }\end{array}$ & $1,8^{\circ} \mathrm{C}$ \\
\hline Zaidan et. al. & 2017 & Artigo & $\begin{array}{c}\text { Belo } \\
\text { Horizonte, } \\
\text { MG }\end{array}$ & $\begin{array}{l}\text { Cwa - Clima } \\
\text { Temperado } \\
\text { Úmido com } \\
\text { Inverno Seco } \\
\text { e Verão } \\
\text { Quente }\end{array}$ & $\begin{array}{c}\text { Diurno - } \\
\text { Primavera }\end{array}$ & Praças & $\begin{array}{l}\text { Medição em } \\
\text { Campo }\end{array}$ & $3,1^{\circ} \mathrm{C}$ \\
\hline
\end{tabular}

Fonte: Desenvolvido pelos autores 
Os documentos foram agrupados de acordo com os métodos de análise utilizados (medições de campo, geoprocessamento e/ou simulação computacional) e pela característica funcional do suporte (parques, praças, arborização em calçadas, fachadas vegetadas e/ou coberturas vegetadas).

Foram analisados o método e os objetivos dos documentos, para verificar se houve algum processo que pudesse comparar a temperatura do ar, com e sem a vegetação, e com o mínimo possível de intervenções de outros parâmetros ambientais.

Para cada documento analisado, também foram coletados o local do estudo e o seu respectivo clima segundo a classificação de Koppen e Geiger (KÖPPEN et al., 1930), o período de análise, e a diferença máxima de temperatura do ar encontrada.

A classificação climática de Köppen-Geiger, adaptada e atualizada para o Brasil por Alvares et al. (2013), possui algumas limitações, porém é a mais adotada, mundialmente. Esta classificação utiliza a vegetação natural para representar o clima, e a sua classificação depende apenas das variações de temperatura e das frequências das precipitações.

A Tabela 2 apresenta uma síntese dos documentos selecionados, classificados por tipo de documento (artigos, dissertações e teses), pela metodologia de análise (geoprocessamento, levantamento de campo e simulação computacional) e pela tipologia de suporte para a vegetação analisada (via urbana, praça, parque, coberturas ou fachadas).

Tabela 2: Quadro síntese dos documentos por categoria e área de estudo

\begin{tabular}{|c|c|c|c|c|c|}
\hline $\begin{array}{l}\text { Metodologia de } \\
\text { Medição }\end{array}$ & $\begin{array}{l}\text { Tipologia de Suporte da } \\
\text { Vegetação }\end{array}$ & $\begin{array}{r}\text { Quantidade de } \\
\text { Artigos }\end{array}$ & $\begin{array}{l}\text { Quantidade de } \\
\text { Dissertações }\end{array}$ & $\begin{array}{r}\text { Quantidade } \\
\text { de Teses }\end{array}$ & $\begin{array}{r}\text { Total de } \\
\text { Documentos }\end{array}$ \\
\hline \multirow[t]{6}{*}{ Medição em Campo } & $\begin{array}{l}\text { Arborização em vias } \\
\text { urbanas }\end{array}$ & 17 & 6 & 3 & 26 \\
\hline & Fachadas de Edificações & 0 & 0 & 0 & 0 \\
\hline & Coberturas & 1 & 1 & 1 & 3 \\
\hline & Praças & 11 & 5 & 1 & 17 \\
\hline & Parques & 4 & 4 & 1 & 9 \\
\hline & Sub Total & 33 & 16 & 6 & 55 \\
\hline \multicolumn{2}{|l|}{ Geoprocessamento } & 9 & 3 & 2 & 14 \\
\hline \multirow[t]{6}{*}{$\begin{array}{l}\text { Simulação } \\
\text { Computacional }\end{array}$} & $\begin{array}{l}\text { Arborização em vias } \\
\text { urbanas }\end{array}$ & 5 & 3 & 1 & 9 \\
\hline & Fachadas de Edificações & 0 & 1 & 0 & 1 \\
\hline & Coberturas & 0 & 0 & 2 & 2 \\
\hline & Praças & 4 & 2 & 2 & 8 \\
\hline & Parques & 0 & 0 & 2 & 2 \\
\hline & Sub Total & 9 & 6 & 7 & 22 \\
\hline \multicolumn{2}{|c|}{ Total de Documentos } & 51 & 25 & 15 & 91 \\
\hline
\end{tabular}

A Figura 1 apresenta, graficamente, a quantificação dos documentos analisados por categoria e pelo método adotado na pesquisa. As medições realizadas em campo apresentam maior ocorrência que as simulações computacionais e do que os trabalhos utilizando o geoprocessamento. A maior parte dos trabalhos utilizando simulação computacional também realizou medições de campo, para calibrar o software de simulação. 
Figura 1: Quantificação dos documentos analisados por categoria e método de pesquisa

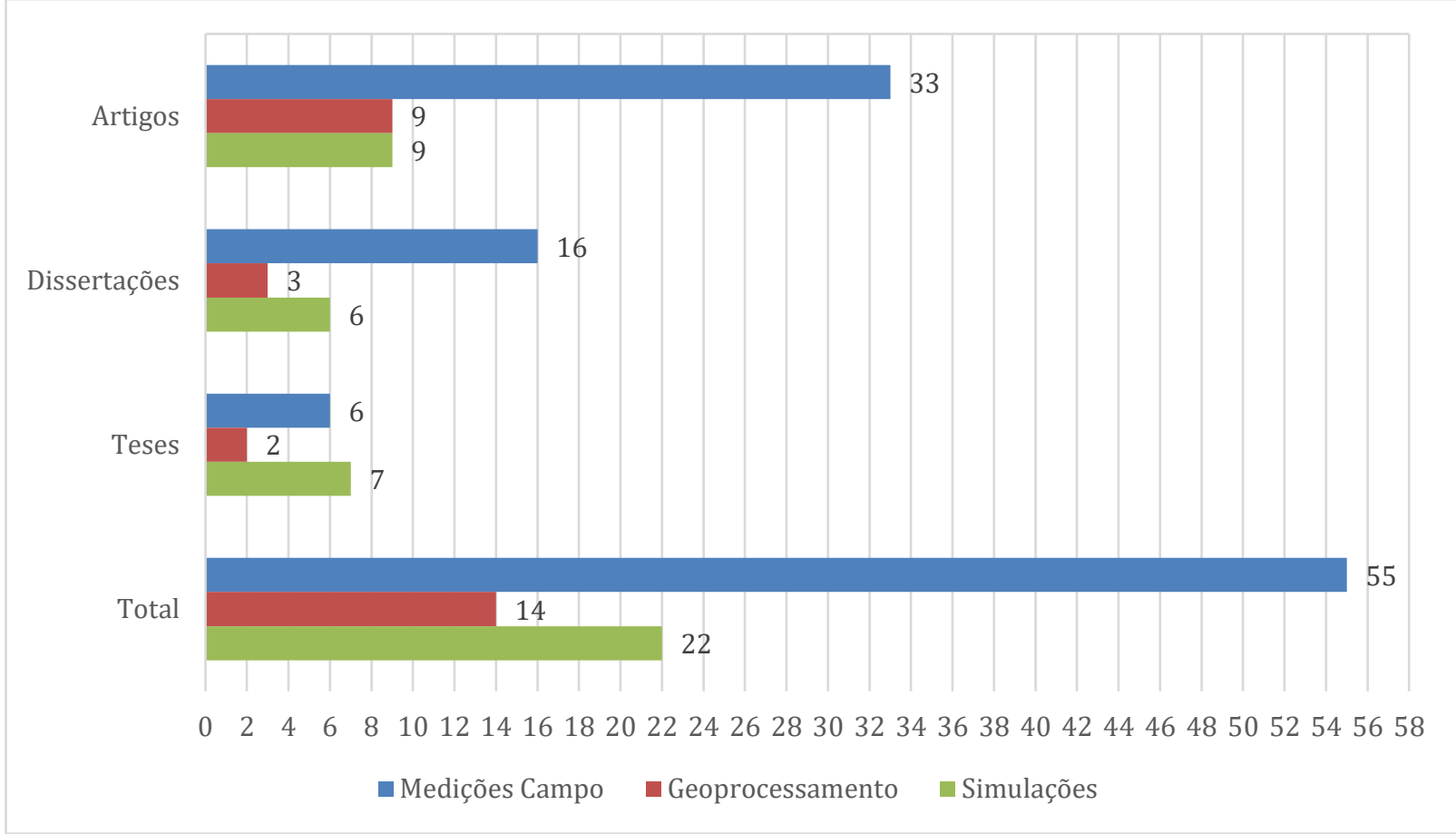

Fonte: Desenvolvido pelos autores

A figura 2 apresenta, graficamente, a quantificação das pesquisas analisadas por categoria e pela tipologia de suporte da vegetação. A maioria dos estudos analisou as praças e a arborização em vias urbanas, seguido dos estudos usando geoprocessamento, parques, e em menor quantidade, o estudo da vegetação na cobertura das edificações. Foi encontrado apenas um documento com estudos sobre a influência da vegetação na temperatura do ar externo aplicada em superfícies verticais, como em muros, paredes e fachadas. 
Figura 2: Síntese de tipos de documentos pesquisados e tipo de aplicação da vegetação

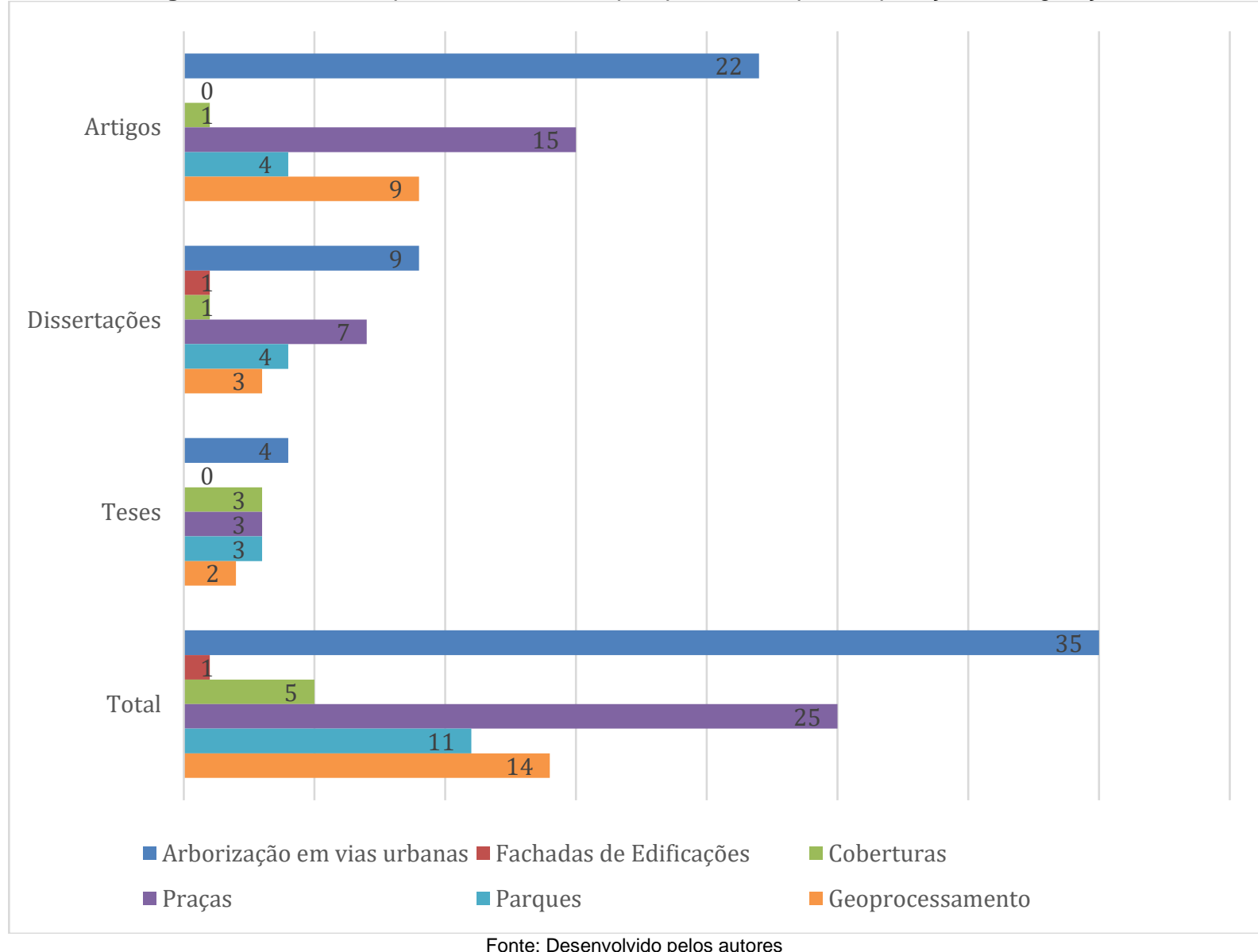

A classificação dos trabalhos analisados pelas regiões climáticas brasileiras é apresentada na Figura 3. O clima Tropical com Estação Seca de Inverno (Aw) é o que apresenta maior ocorrência, com 26 pesquisas selecionadas. Este clima é encontrado em 25,8\% do território brasileiro, característico de cidades como Cuiabá, Brasília, Palmas, Teresina e São Luis do Maranhão. A segunda maior ocorrência é do clima Tropical Úmido com Verão Temperado (Cfb). Este clima ocorre nas cidades de São Paulo e Curitiba, onde há um grande número de pesquisas relacionadas ao Conforto Ambiental. Em seguida, foram encontradas 17 pesquisas com pesquisas em clima de Monção, 16 pesquisas em clima Tropical Úmido com Verão Quente, 4 pesquisas em Clima Temperado Úmido com Inverno Seco e Verão Temperado, 3 pesquisas em Clima Tropical com Estação Seca de Verão, e apenas 1 pesquisa em Clima Tropical Úmido, na cidade de Manaus.

Não foram encontradas pesquisas para o Clima das Estepes Quentes de Baixa Latitude e Altitude (Bsh) e para o Clima Temperado Úmido com Inverno Seco e Verão Quente (Cwa). O Brasil possui 420 cidades em clima Bsh e 407 cidades em clima Cwa, representando respectivamente 4,9\% e 2,5\% da área do país. 
Figura 3: Quantidade de pesquisas por região climática

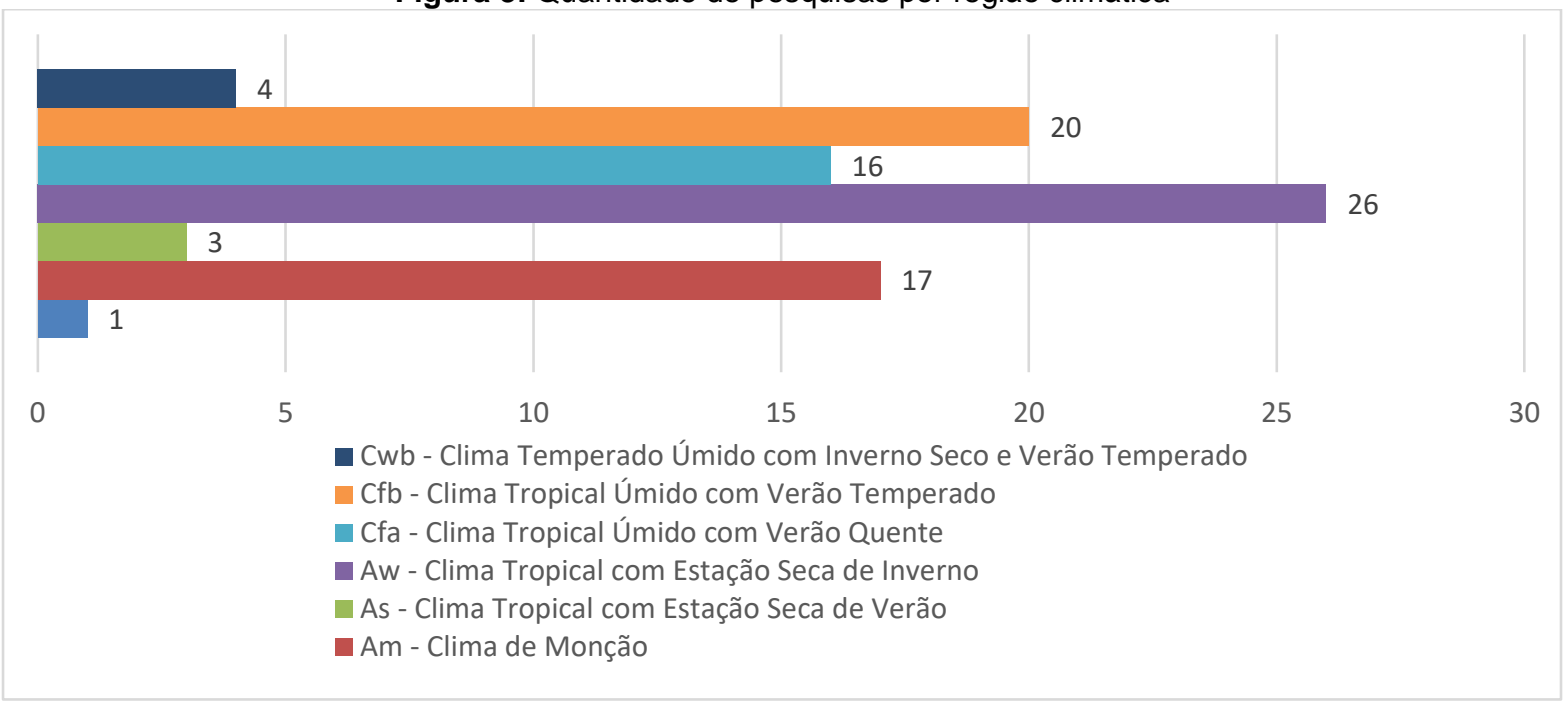

Fonte: Desenvolvido pelos autores

A quantidade de documentos produzidos ao longo do período analisado é apresentada na Figura 4. Houve um aumento da produção de documentos a partir de 2009. O primeiro trabalho utilizando simulação computacional foi publicado em 2009, e o primeiro trabalho encontrado utilizando geoprocessamento foi publicado em 2003.

Figura 4: Quantidade de Documentos por Ano

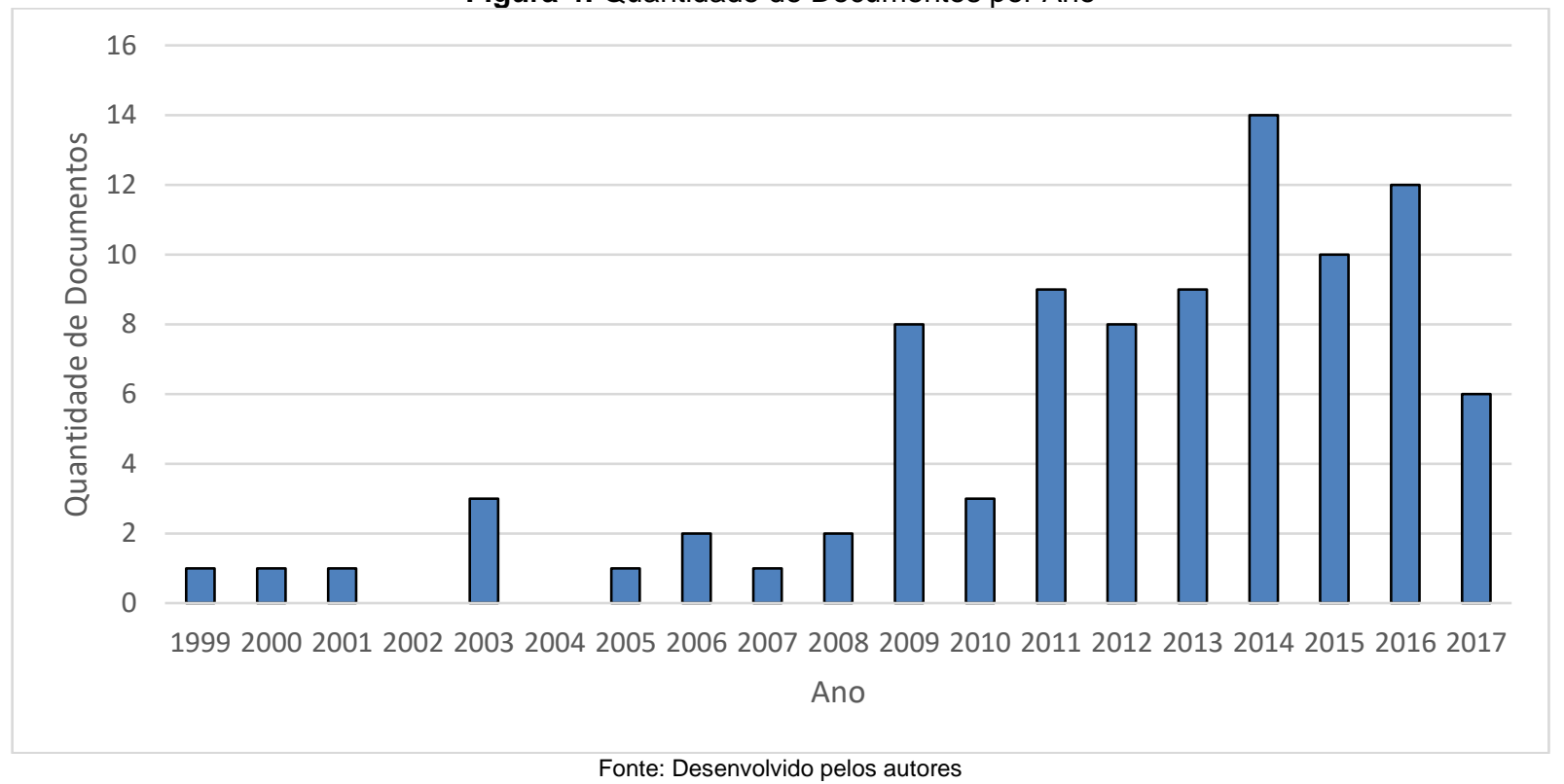

Fonte: Desenvolvido pelos autores

\section{CONSIDERAÇÕES FINAIS}

Os documentos analisados demonstraram evidências que a utilização da vegetação nos ambientes urbanos é importante para diminuir a temperatura do ar. Uma quantidade maior de pesquisas é necessária para que seja possível estabelecer uma associação entre a influência da vegetação e os diferentes climas encontrados no Brasil, espécies, índices de área foliar (LAI), densidades, distribuição, tipo de aplicação e metodologia de análise. 
Nos estudos utilizando medições de campo, há uma variação muito grande na escolha da frequência e dos períodos das medições. Algumas pesquisas foram muito extensas, com muitas medições e/ou simulações, ao longo do dia e durante um ano inteiro. Em outros trabalhos foram tomados resultados pontuais, para apenas um dia, ou mesmo com uma única medição.

A maior parte das pesquisas foi realizada no período diurno, porém há algumas pesquisas que analisaram o período noturno e outras que realizaram análise diurna e noturna. O período do ano em que foram feitas as análises também variaram entre os documentos analisados, com predominância dos estudos nos meses de verão.

A utilização de simulações de diferentes cenários em computador permite um controle maior sobre as diferentes variáveis que podem influenciar na temperatura do ar, entretanto mais pesquisas são necessárias para definir as variáveis dos softwares, possibilitando maior aproximação com as condições físicas reais.

Os estudos utilizando o geoprocessamento, apesar de apresentarem uma precisão menor, conseguem fazer uma analogia mais direta entre a quantidade de áreas vegetadas e a sua influência na temperatura do ar, inclusive sendo possível comparar as temperaturas de diferentes regiões para o mesmo período temporal.

\section{Referências}

ALVARES, C.A., STAPE, J.L., SENTELHAS, P.C., GONÇALVES, J.L.M.; SPAROVEK, G. Köppen's climate classification map for Brazil. Meteorologische Zeitschrift, Stuttgart, Vol. 22, No. 6, págs. 711728, 2013.

AVISSAR, B. Potential effects of vegetation on the urban thermal environment. Atmospheric Environment, Fukouka, № 30(3), págs. 437-448. 1996.

BARTHOLOMEI, C. L. B. Estudo da atenuação da radiação solar incidente por diferentes espécies arbóreas. Dissertação (Mestrado em Engenharia Civil), UNICAMP, Campinas, 1998.

BONAN, G.B. Effects of land use on the climate of the United States. Climate Change, № 37, págs. 449-486. 1997.

CHEN, Y. WONG, N.H. Thermal benefits of city parks. Energy and Buildings, № 38, págs. 105-120. 2006.

GIVONI, B. Impact of planted areas on urban environmental quality: a review. Atmospheric Environment, № 25, págs. 289-299. 1991.

GRIMMOND, C.S.B. OKE, T.R. An evapotranspiration-interception model for urban areas. Water Resource Res., № 27, págs. 1739-1755. 1991.

HEISLER, G.M. WANG, Y. Semi-empirical modelling of spacial differences in below-canopy urban air temperature using GIS analysis of satellite images, onsite photography and meteorological measurements. 23rd conference on agricultural and forest meteorology. American Meteorological Society, Boston, págs. 206-209. 1998.

HUANG, L. Li, J. ZHAO, D. ZHU, J. A fieldwork study on the diurnal changes of urban microclimate in four types of ground cover and urban heat island of Nanjing, China. Building Environment, № 43, págs. 7-17. 2008. 
HUNG, T. UCHIHAMA, D. OCHI, S. YASUOKA, Y. Assessment with satellite data of the urban heat island effects in Asian mega cities. International Journal of Applied Earth Observatory Geoinformation № 8, págs. 34-48. 2006.

JOHANSSON, E., EMMANUEL, R. The influence of urban design on outdoor thermal comfort in the hot, humid city of Colombo, Sri Lanka. International Journal of Biometeorol., № 51, págs. 119-133. 2006.

KÖPPEN, W.P., GEIGER, R., MILANKOVITCH, M., CONRAD, V., BORCHARDT, W., WEGENER, K., WAGNER, A. Handbuch Der Klimatologie, vol. 3. Berlim, Alemanha. 1930.

LOIS, E. LABAKI, L.C. Conforto Térmico em Espaços Externos: Uma Revisão. Anais do VI Encontro Nacional e III Encontro Latino Americano Sobre Conforto no Ambiente Construído. São Pedro, 2001.

OKE, T.R. The micrometeorology of the urban forest. Philosofical Transaction of the Royal Society B. № 324, págs. 335-349. Londres, 1989.

SANTAMOURIS, M. Energy and Climate in the Urban Built Environment. Londres. James and James Science Publishers, 2001.

TAHA, $\mathrm{H}$. Urban climates and heat islands: albedo, evapotranspiration, and anthropogenic heat. Energy and Buildings № 25, págs. 99-103. 1997.

TIANGCO, M. LAGMAY, A.M.F. ARGETE, J. ASTER-based study of the night-time urban heat island effect in Metro Manila. International Journal of Remote Sensoring № 29, págs. 2799-2818. 2008.

WONG, N.H., TAN, P.Y., CHEN, Y. Study of thermal performance of extensive rooftop greenery systems in the tropical climate. Building Environment № 42, págs. 25-54. 2007.

\section{MEDIÇÕES EM CAMPO - ÁRBORIZAÇÃO EM VIAS URBANAS}

ALBUQUERQUE, M. M., LOPES, W. G. R. Influência da Vegetação em Variáveis Climáticas: Estudo em Bairros da Cidade de Teresina, Piauí. Revista Ra'e Ga, Curitiba, v. 36, p 38 - 68, abr. 2016.

ALVES A. K. JESUS A. T. C. MACÊDO K. C. SAMPAIO M. M. A. Avaliação do Conforto Urbano Sob a Influência da Vegetação na Cidade de Cuiabá - MT. E\&S - Engineering and Science, 2017.

ALVES, D. B. FIGUEIRÓ, A. S. Vegetação Urbana e Variabilidade do Campo Térmico em Áreas Selecionadas da Cidade d Santa Maria, Revista Geonorte,, V.2, N.4, p.1111 - 1125, 2012.

BARBOSA, R. V. R. BARBIRATO, G. M. VECCHIA, F. A. S. Vegetação Urbana: Análise Experimental em Cidade de Clima Quente e Úmido, Anais do Encac Cotedi. Curitiba, 2003.

BEZERRA, P. T. C. Caracterização de ilhas de calor e conforto térmico em áreas urbanas do semiárido brasileiro. Tese (Doutorado em Recursos Naturais), Centro de Tecnologia e Recursos Naturais, Universidade Federal de Campina Grande, Campina Grande, 2013.

DA COSTA, E. R. O Campo Térmico e a Qualidade Ambiental Urbana Em Chapecó/SC. Tese (Doutorado em Geografia),UNESP, Presidente Prudente, 2015.

GONÇALVES, A. CAMARGO, L. S. SOARES, P. F. Influência da Vegetação no Conforto Térmico Urbano: Estudo de Caso na Cidade de Maringá - Paraná. Anais do III Simpósio de Pós-Graduação em Engenharia Urbana. 2012.

JÚNIOR, A. P. JESUS, E. S. BASTOS, M. B. F. SANTOS, R. V. C., Microclima e a arborização: o caso de duas áreas do Núcleo Marabá Pioneira, Marabá - Pará. Ecologia e Nutrição Florestal, Santa Maria, v.4, n.2, p.54-67, mai./ago. 2016. 
KRÜGER, E. L., BARBOSA, M. A., A Influência da Vegetação no Microclima de Áreas Residenciais e na Tecnologia Construtiva: Estudo de Caso Realizado na Vila Tecnológica de Curitiba. Anais do ENTAC, Fortaleza, 2008.

LEAL, L. BIONDI, D. BATISTA, A. C. Efeitos da Vegetação na Variação Térmica da Cidade de Curitiba, PR. Floresta, Curitiba, v. 44, No 3, p. 451 - 464, jul. / set. 2014.

MALENTACHI, I. F. Levantamento da Vegetação Arbórea e Avaliação do Conforto Térmico das Cinco Espécies de Maior Incidência de Uruaçu, GO. Dissertação (Mestrado Em Ecologia e Produção Sustentável), PUC-Goiás, Goiânia, 2013.

MARTINI, A. GRISE, M. M. BIONDI, D. FILHO, D. F. S. Imagens de Alta Resolução Espacial para Analisar a Influência da Cobertura Arbórea no Microclima das Ruas de Curitiba- PR. REVSBAU, Piracicaba, v.9, n.4, p 32-45, 2014.

MARTINI, A. Microclima e Conforto térmico Proporcionado Pelas Árvores De Rua Na Cidade De Curitiba - Pr. Dissertação (Mestre em Engenharia Florestal), UFPR, Curitiba, 2013.

MASCARELLO, A. V. S. BARBOSA, L. ASSIS, E. S. Efeitos da Vegetação Viária no Conforto Térmico Urbano, Anais do XIV ENCAC - X ELACAC. Balneário Camboriú. 2017.

NINCE, P. C. C. SANTOS, F. M. M. NOGUEIRA, J. S. NOGUEIRA, M. C. J. A., Conforto térmico dos usuários em vegetação e revestimento urbanos no campus da UFMT em Cuiabá - MT. Revista Monografias Ambientais - REMOA v.13, n.4, set-dez. p.3529-3541. 2014.

PAZ, L. H. F. A Influência sobre o Clima Urbano de Palmas - TO. Dissertação (Mestrado em Arquitetura e Urbanismo), UnB, Brasília, 2009

RAMALDES, R. A. C. Influência da Vegetação no Conforto Térmico do Transeunte: Estudo de Caso em Via com Canteiro Central em Vitória, ES. Dissertação (Mestrado em Arquitetura e Urbanismo), Centro de Artes, UFES, Vitória, 2015.

ROCHA, L. M. V. SOUZA, L. C. L. CASTILHO, F. J. V. Ocupação do solo e ilha de calor noturna em avenidas marginais a um córrego urbano. Ambiente Construído, Porto Alegre, v. 11, n. 3, p. 161-175, jul./set. 2011.

ROCHA, V. M. FIALHO, E. S. Uso da terra e suas implicações na variação termo-higrométrica ao longo de um transeto campo-cidade no município de Viçosa-MG, Revista de Ciências Humanas, Vol. 10, № 1, p. 64-77, jan./jun. 2010.

RODRIGUES, J. E. C., Análise das Características Socioambientais na Cidade De Belém/PA: Um Estudo da Vegetação e Clima Urbano. Tese (Doutorado em Geografia), UNESP, Presidente Prudente, 2017.

SOUZA, C. A. Análise do Conforto Térmico de Parques Urbanos de Recreação e de suas Áreas de Influência na Cidade de Campo Grande - MT. Dissertação (Mestrado em Meio Ambiente e Desenvolvimento Regional), Uniderp, Campo Grande, 2016.

TEIXEIRA, P. H. L. LUCAS, T. P. B. A Influência da Vegetação em um Microclima da Cidade de Belo Horizonte, MG. Caderno de Geografia, v.24, n.42, 2014.

XAVIER, A. L. M. NOGUEIRA, C. J. A., MAITELLI, G. T., OliVEIRA A. G. OLIVEIRA, A. S., SANTOS, F. M. M., NOGUEIRA J. S. Variação da Temperatura e Umidade entre Áreas Urbanas de Cuiabá. Engenharia Ambiental, Espírito Santo do Pinhal, v. 6, n. 1, p. 082-093, jan/abr 2009.

\section{MEDIÇÕES EM CAMPO - ÁRBORIZAÇÃO EM PRAÇAS}

ABREU, L. V. Estudo do raio de influência da vegetação no microclima por diferentes espécies arbóreas. Dissertação (Mestrado em Engenharia Civil), UNICAMP, Campinas, 2008. 
ALVES, W. S. A Vegetação e sua Influência no Microclima Urbano, Élisée, Rev. Geo. Anápolis, v.5, n.1, p.205-221, jan. /jun. 2016.

ARAÚJO, R. R. CALDAS, C. S. Clima Urbano e Vegetação: Análise da Influência da Vegetação da APA do Itapiracó no Microclima e Conforto Térmico Local em São Luís (MA). Anais do XII SBCG. 2016.

BARBOSA, E. T. AMO, V. A. LABAKI, L. C. A Influência da Vegetação e das Variáveis Climáticas no Nível de Conforto dos Usuários da Praça do Centro de Convivência em Campinas, SP. Anais do XIII ENTAC, Canela, 2010.

BORGES, Marcus Gonçalves Euclydes. Influência do Ambiente Construído no Microclima Urbano: estudo de caso no campus da Universidade Federal de Santa Catarina. Dissertação (Mestrado em Arquitetura e Urbanismo), UFSC. Florianópolis, 2006.

CAVALCANTE, M. R. C. ÁVILA, I. BARBIRATO, G. M. Efeito Microclimático da Presença de Vegetação em Recintos Urbanos em Maceió - AL. Anais do ENCAC - ELACAC, Maceió, 2005.

DINIZ JÚNIOR, J. A Influência da Vegetação no Índice de Conforto Térmico em Praças de Diferentes Configurações Morfológicas na Cidade de Santarém-PA. Dissertação (Mestrado em Recursos Naturais da Amazônia), UFOPA, Santarém, 2012.

FERREIRA, C. C. M. ASSIS, D. C. PIMENTEL F. O. OLIVEIRA D. E. O Estudo do Microclima Gerado por Praças em Relação aos Seus Arredores na Cidade de Juiz de Fora - MG. Anais do X Simpósio Brasileiro de Climatologia Geográfica. Manaus, Amazonas, 2012.

GOMES, M. A. S. AMORIM, M. C. C. T. Arborização e Conforto Térmico no Espaço Urbano: Estudo de Caso nas Praças Públicas de Presidente Prudente (SP). Caminhos de Geografia, 7(10)94-106, set. 2003.

JÚNIOR (1), J. D. COSTA, A. C. L. SANTOS, M. R. P. VIEIRA, L. C. R. OLIVEIRA, A. A. R. OLIVEIRA, L. L. Influência da Vegetação nos Parâmetros Micrometeorológicos da Área Urbana de uma Cidade de Médio Porte da Amazônia. Revista Ciência e Natura, Santa Maria, dez. p. 264 - 266. 2013.

LIMA, D. C. R. NUNES, L. A. SOARES, P. F. Avaliação da Influência da Vegetação no Conforto Térmico em Espaços Livres. Anais do SIMPGEU. Maringá. PR. 2009.

OLIVEIRA, M. M., ALVES, W. S. Influência Da Vegetação No Clima Urbano De Cidades Pequenas: Um Estudo Sobre As Praças Públicas De Iporá-GO. Revista Territorial - Goiás, v.2, n.2, p.61-77, jul./dez. 2013.

SOUZA, S. M. Mapeamento e Avaliação da Vegetação Urbana da Cidade de Vitória - ES, Utilizando Geotecnologias, Dissertação (Mestrado em Ciências Florestais), UFES, Jerônimo Monteiro, 2011.

VASCONCELLOS, V. M. N. O Entorno Construído e o Microclima em Praças em Cidades de Clima Tropical Quente e Úmido: Uma Contribuição Metodológica Para o Projeto Bioclimático. Tese (Doutorado em Arquitetura e Urbanismo), UFRJ, Rio de Janeiro, 2006.

ZAIDAN, C. G. ASSIS, E. S. ROCHA, M. S. S. BARROS, B. F. VILELA, J. A. SÁ, A. J. O. RIBEIRO, C. GUIDI, C. R. FREITAS, T. P. F. B. KATZSCHNER, V. L. Avaliação da Influência da Vegetação Arbórea no Microclima: Estudo de Caso na Praça da Liberdade, Belo Horizonte, MG. Anais do XIV ENCAC - X ELACAC. Balneário Camburiú,2017.

\section{MEDIÇÕES EM CAMPO - ÁRBORIZAÇÃO EM PARQUES}

CARVALHO, M. M. Clima Urbano e Vegetação: Estudo Analítico e Prospectivo do Parque das Dunas em Natal. Dissertação (Mestrado em Arquitetura e Urbanismo), UFRN, Natal, 2001

CASTRO, L. L. F. L. Estudo de parâmetros de conforto térmico em áreas verdes inseridas no ambiente urbano, Campinas. Dissertação (Mestrado em Engenharia Civil), UNICAMP, Campinas, 1999. 
DE ZORZI, L. M. A Influência dos Parques Verdes no Conforto Térmico Urbano: Estudo de Caso em Porto Alegre - RS. Dissertação (Mestrado em Planejamento Urbano e Regional), UFRGS, Porto Alegre, 2016.

DUARTE (1), D. GONCALVES, J. MONTEIRO, L. M. Urban Design and Thermal Comfort: Assessment of Open Spaces in Barra Funda, A Brownfield Site in São Paulo, by Means of Site Measurements and Predictive Simulations. Anais do Seventh Symposium on the Urban Environment, San Diego, 2007.

DUARTE (2), D. H. S. Padrões de Ocupação do Solo e Microclimas Urbanos na Região De Clima Tropical Continental. Tese (Doutorado em Arquitetura), USP, São Paulo, 2000.

JUNIOR (3), V. L. F. N. A Influência da Vegetação sobre o Clima Urbano de Curitiba - PR: Estudo De Caso. Especialização (Especialização em Análise Ambiental), UFPR, Curitiba, 2015.

LEAL, L. BIONDI, D. BATISTA, A. C. Influência das Florestas Urbanas na Variação Termo-Higrométrica da Área Intraurbana de Curitiba - PR. Ciência Florestal, Santa Maria, v. 24, n. 4, p. 807-820. 2014.

REIS, D. S. Avaliação do Efeito de Florestas Urbanas e Áreas Vegetadas no Conforto Higrotérmico. Dissertação (Mestrado em Ciências), USP, Piracicaba, 2014.

SILVA, B. A. XAVIER, T. C. ALVAREZ, C. E. A Influência da Vegetação no Conforto Térmico para a Condição Microclimática de Vitória (ES). Cidades Verdes, v.03, n.08, 2015, pp. 01-15. 2015

\section{MEDIÇÕES EM CAMPO - COBERTURAS VERDES}

CATUZZO, H. Telhado Verde: Impacto Positivo na Temperatura e Umidade do Ar da Cidade de São Paulo. Tese, (Doutorado em Geografia Física), USP, São Paulo, 2013.

ROSSETI, K. A. C. NOGUEIRA, M. C. J. A., FRANCO, F. M., NOGUEIRA, J. S. Análise da Interferência da Cobertura Verde na temperatura e Umidade Relativa do Ar no Entorno de uma Edificação - Estudo de Caso em Protótipo no Município de Cuiabá, MT. Anais do XI ENCAC - VII ELACAC. Búzios, RJ. 2011.

SARKA, K. Um Estudo Comparativo Sobre a Contribuição dos Telhados Verdes Para a Mitigação do Efeito de Ilha de Calor Urbana: Um Experimento na Cidade do Rio de Janeiro. Dissertação (Mestrado em Arquitetura e Urbanismo), UFRJ, Rio de Janeiro, 2016.

\section{SIMULAÇÃO COMPUTACIONAL - ÁRBORIZAÇÃO EM VIAS URBANAS}

BARROS, C.P.G. COSTA, S.B. BARBOSA, R.V.R. Vegetação e Microclima Urbano: Estudo de Caso em Ruas Residenciais de Bairros Litorâneos em Maceió-Alagoas, Anais do Pluris, 7ํ Congresso Luso Brasileiro para o Planejamento Urbano, Regional, Integrado e Sustentável, Maceió, Alagoas. 2016.

ELSING, L. P. O Processo de Densificação e a Modificação do Microclima: Um Estudo Comparativo no Bairro Vila Leopoldina na Cidade De São Paulo. Dissertação (Mestrado em Urbanismo), Universidade Federal do Rio de Janeiro, 2016.

FREDERICO E SILVA, C. Caminhos Bioclimáticos: Desempenho Ambiental De Vias Públicas Na Cidade De Teresina - PI. Dissertação (Mestrado em Arquitetura e Urbanismo), UnB, 2009.

MARRA, N. MORILLE, B. ASSIS, E. Influência da Vegetação no Conforto Térmico em Conjunto Habitacional de Interesse Social. Anais do XIV ENCAC - X ELACAC. 2017.

MINELLA, F. C. O. Desenho Urbano Climaticamente Orientado: A Influência Da Vegetação No Ambiente Térmico Externo. Tese (Doutorado em Tecnologia), UTFPR, Curitiba, 2014.

MINELLA, F. C. O. HONJO, S. KRÜGER, E. L. Estratégias de Melhoria do Ambiente Térmico Diurno em Situação de Verão de uma Fração Urbana da Cidade de São Paulo. Ambiente Construído, Porto Alegre, v.12, n. 4, p. 139-158, out./dez. 2012. 
PEZZUTO, C. C. ALCHAPAR, N. L. LABAKI, L. C. CORREA, E. N. Efeito da Vegetação na Variação da Temperatura Urbana em Diferentes Climas: Estudo de Caso na Cidade de Campinas e Mendonza. Anais do XIII ENCAC - IX ELACAC. 2015

VASCONCELOS, J. S. Índices Urbanísticos e o Meio Ambiente Térmico: Estudo em uma Fração da Cidade de São Carlos - SP. Dissertação (Mestrado em Engenharia Urbana), UFSCAR, São Carlos, 2014.

VIEIRA, F. C. PEZZUTO, C. C. Análise do Impacto da Vegetação no Microclima de Áreas Residenciais de Baixa Densidade Através de Simulação Computacional no Programa Envi-Met. Anais do V Encontro de Iniciação em Desenvolvimento Tecnológico e Inovação. 22 e 23 de setembro de 2015.

\section{SIMULAÇÃO COMPUTACIONAL - ÁRBORIZAÇÃO EM PRAÇAS}

ASSIS, E. S. SIRQUEIRA, C. A. BAMBERG, A. M. Influência da Vegetação no Microclima em Ambiente Simulado Controlado. XII ENCAC - VIII ELACAC. Brasília. 2013.

CARFAN, A. C. Análise do Conforto Térmico em Áreas Abertas no Município de Ourinhos - SP. Tese (Doutorado em Geografia), USP, São Paulo, 2011.

CASTELO BRANCO, L. M. B. Microclimas urbanos no Plano Piloto de Brasília: o caso da superquadra 108 sul. Dissertação (Mestrado em Arquitetura e Urbanismo), UnB, Brasília, 2009.

DOBBERT, L. Y. Arborização na Cidade de Campinas/SP - Percepção e Conforto. Tese (Doutorado em Ciência), USP, Piracicaba, 2015

HEERDT, C. OlivEIRA, M. C. A. Um Estudo Sobre a Influência da Arborização na Praça da Avenida Ns15 da Quadra 307 Norte. Revista Desafios, Vol. 3, Número Especial, p. 34-48. 2017.

PASTRO, L. C. CALLEJAS, I. J. A. NOGUEIRA, M. C. J. A. DURANTE, L. C. Influência da Vegetação No Microclima De Pátios Escolares Em Clima Quente. Anais do Congresso Luso Brasileiro para o Planejamento Urbano, Regional, Integrado e Sustentável - PLURIS, Brasília, v.1. 2012.

SHINZATO, P. DUARTE, D. H. S. Quantificação da Intensidade e a Distribuição Espacial dos Efeitos Microclimáticos da Vegetação. Anais do XI ENCAC - VII ELACAC. Búzios, RJ. 2011.

SHINZATO, P. O Impacto da Vegetação nos Microclimas Urbanos. Dissertação (Mestrado em Arquitetura e Urbanismo), USP, São Paulo, 2009.

\section{SIMULAÇÃO COMPUTACIONAL - ARBORIZAÇÃO EM PARQUES}

DUARTE (3), D. H. S. O Impacto da Vegetação no Microclima em Cidades Adensadas e Seu Papel na Adaptação aos Fenômenos de Aquecimento Urbano. Tese (Livre Docencia Departamento de Tecnologia da Arquitetura), USP, São Paulo. 2015.

SHINZATO, P. O Impacto da Vegetação nos Microclimas Urbanos em Função da Interações SoloVegetação-Atmosfera. Tese (Doutorado em Arquitetura e Urbanismo), USP, Şão Paulo, 2014.

\section{SIMULAÇÃO COMPUTACIONAL - COBERTURA VERDES}

MACIEL, C. R. Condições Microclimáticas de Espaços Abertos: Simulação de Estratégias por meio do Software ENVII-Met, Tese (Doutorado em Física Ambiental),UFMT, Cuiabá,2014.

ROSSETI, K.A.C. Efeitos do uso de telhados vegetados em ilhas de calor urbanas com simulação pelo software ENVI-Met. Tese (Doutorado em Física Ambiental), UFMT, Cuiabá, 2013.

\section{SIMULAÇÃO COMPUTACIONAL - FACHADAS VERDES}

SORTE, P. D. B. Simulação Térmica de Paredes Verdes Compostas de Vegetação Nativa do Cerrado. Dissertação (Mestrado em Arquitetura e Urbanismo), UnB. Brasília, 2016 


\section{GEOPROCESSAMENTO}

ALMEIDA, A. J. P. JUNIOR, S. A. M. G. ANDRADE, E. L. NETO, J. V. F. Relação entre o Índice de Vegetação e a Temperatura de Superfície na estimativa e identificação das ilhas de calor na cidade de Maceió-AL. Anais XVII Simpósio Brasileiro de Sensoriamento Remoto - SBSR, João Pessoa, PB. 2015.

AMORIM, M. C. C. T. DUBREUIL, V. CARDOSO, R. S. Modelagem Espacial da llha de Calor Urbana em Presidente Prudente (SP) - Brasil, Revista Brasileira de Climatologia, Ano 11 - Vol. 16 - jan/jul 2015.

BARROS, H. R. A Relação entre a llha de Calor Urbana, uso e Cobertura do Solo e o Balanço de Energia no Município de São Paulo: Avaliação do Campo Térmico nos Parques Públicos de Lazer. Tese (Doutorado em Ciências), USP, São Paulo, 2016.

BIAS, E. S. BAPTISTA, G. M. M. LOMBARDO, M. A. Análise do Fenômeno de llhas de Calor Urbanas, por Meio da combinação de Dados Landsat e Ikonos, Anais XI SBSR, Belo Horizonte, 05 - 10 abril, p. 1741 - 1748. 2003.

CALLEJAS, I. J. A. DURANTE, L. C. OLIVEIRA, A. S. NOGUEIRA, M. C. J. A. Uso do Solo e Temperatura Superficial em Área Urbana. Mercator, Fortaleza, v. 10, n. 23, p. 207-223, set./dez. 2011.

COSTA, D. F. SILVA, H. R. PERES, L. F., Identificação de Ilhas de Calor na Área Urbana de llha Solteira - SP Através da Utilização de Geotecnologias, Engenharia Agrícola, Jaboticabal, v.30, n.5, p.974-985, set./out. 2010.

GALlO, B. C. ALVAREZ, I. A. GARÇON, E. A. M. Comparação entre Temperatura de Superfície e Presença de Vegetação Viária em Dois Bairros de Campinas-SP. Anais XVI Simpósio Brasileiro de Sensoriamento Remoto, Foz do Iguaçu, PR, Brasil. 2013.

LUCENA, A. J. A ilha de calor na Região Metropolitana do Rio de Janeiro. Tese (Doutorado em Engenharia Civil), UFRJ, Rio de Janeiro, 2012.

MASHIKI, M. Y. Geoprocessamento na Identificação de Ilhas de Calor e Influência Do Uso e Ocupação do Solo na Temperatura Aparente da Superfície no Município de Botucatu/SP. Dissertação (Metrado em Agronomia), Faculdade de Ciências Agronômicas, UNESP, Botucatu. 2012.

MORAIS, M. V. B. GUERRERO, V. V. U. FREITAS, E. D. Efeito do Tipo de Vegetação Urbana no Conforto Térmico Humano para Ambientes Externos: Um Estudo de Caso para São Paulo, Anais Do X Simpósio Brasileiros De Climatologia Geográfica, p. 220 - 231, 2014.

OLIVEIRA, F. S. Mapeamento da vegetação urbana e distribuição espacial e temporal de ilhas de calor. Dissertação (Mestrado em Ciências Florestais), UFES, Jerônimo Monteiro, 2015.

RAFAEL, R. A. Relação Entre Ilhas de Calor Urbano e Mudanças no Uso da Terra: Um Estudo de Caso Para Manaus - Am. Dissertação (Mestrado em Meteorologia), UFCG, Campina Grande, 2014.

SENA, C. A. P. FRANÇA, J. R. A. PERES, L. F. Estudo da llha de Calor na Região Metropolitana do Rio de Janeiro Usando Dados do MODIS, Anuário do Instituto de Geociências - UFRJ. Vol. 37 - 2 / 2014 p. 111-122.

SOUSA, S. B. FERREIRA L. G. Análise da Temperatura de Superfície em Ambientes Urbanos: um Estudo por Meio de Sensoriamento Remoto no Município de Goiânia, Goiás (2002 - 2011). Confins. Revista Franco Brasileira de Geografia. Número 15. 2012. 